\title{
Wnt Signaling from Development to Disease: Insights from Model Systems
}

\author{
Ken M. Cadigan ${ }^{1}$ and Mark Peifer ${ }^{2}$ \\ ${ }^{1}$ Department of Molecular, Cellular, and Developmental Biology, University of Michigan, \\ Ann Arbor, Michigan 48109-1048 \\ ${ }^{2}$ Department of Biology and Lineberger Comprehensive Cancer Center, University of North \\ Carolina at Chapel Hill, Chapel Hill, North Carolina 27599-3280 \\ Correspondence: peifer@unc.edu
}

One of the early surprises in the study of cell adhesion was the discovery that $\beta$-catenin plays dual roles, serving as an essential component of cadherin-based cell-cell adherens junctions and also serving as the key regulated effector of the Wnt signaling pathway. Here, we review our current model of Wnt signaling and discuss how recent work using model organisms has advanced our understanding of the roles Wnt signaling plays in both normal development and in disease. These data help flesh out the mechanisms of signaling from the membrane to the nucleus, revealing new protein players and providing novel information about known components of the pathway.

M odern biomedical science is a partnership between scientists studying basic cell and developmental processes in model systems and clinicians exploring the basis of human disease. Few fields exemplify this better than Wnt signaling, born 22 years ago with the realization that the oncogene int1 and the Drosophila developmental patterning gene wingless (wg) are homologs (Cabrera et al. 1987; Rijsewijk et al. 1987). Additional connections further fueled research. Drosophila Armadillo (Arm), a component of the $\mathrm{Wg}$ pathway, is the homolog of the cell junction proteins $\beta$-catenin ( $\beta$ cat) and plakoglobin (McCrea et al. 1991; Peifer et al. 1992; Peifer and Wieschaus 1990) joining Wnt signaling and cadherin-based cell adhesion, a connection we still do not fully understand (see Heuberger and Birchmeier 2009). Adenomatous polyposis coli (APC), the tumor suppressor mutated in most colon cancers, binds $\beta$ cat and is a key regulator of Wnt signaling (Rubinfeld et al. 1993; Su et al. 1993), putting the Wnt field even more squarely in the center of cancer research. Here, we outline recent advances in understanding Wnt signaling, casting new light on these critical regulators of development, homeostasis, and disease.

\section{THE CURRENT MODEL OF WNT SIGNALING}

We first outline the reigning model for Wnt signaling, focusing on canonical signaling involving $\beta$ cat (for reviews of alternate Wnt

Editors: W. James Nelson and Elaine Fuchs

Additional Perspectives on Cell Junctions available at www.cshperspectives.org

Copyright (C) 2009 Cold Spring Harbor Laboratory Press; all rights reserved; doi: 10.1101/cshperspect.a002881

Cite this article as Cold Spring Harb Perspect Biol 2009;1:a002881 
K.M. Cadigan and M. Peifer

pathways, see e.g., Fanto and McNeill 2004; Kohn and Moon 2005; Semenov et al. 2007; van Amerongen et al. 2008; Veeman et al. 2003). The key regulated Wnt effector is $\beta$ cat. In cells not receiving signal, $\beta$ cat accumulates in adherens junctions, but outside junctions $\beta$ cat levels are low, because of its short half-life (Fig. 1, left). Free $\beta$ cat is bound by the multiprotein "destruction complex" (Clevers 2006), in which the tumor suppressors APC and Axin present $\beta$ cat to the kinases glycogen synthase kinase 3 (GSK3) and casein kinase I (CKI), facilitating sequential phosphorylation of sites in ßcat's amino terminus. An SCF-class E3ubiquitin ligase containing the F-box protein $\mathrm{Slimb} / \beta \operatorname{TrCP}$ recognizes correctly phosphorylated $\beta$ cat, and targets it for polyubiqitination and proteasomal destruction. Meanwhile, TCF/LEF proteins bound to Groucho-family corepressors keep Wnt target genes tightly off (Arce et al. 2006).

Wnts bind a two-part receptor: a seventransmembrane Frizzled $(\mathrm{Fz})$ and LRP5/6
(Fig. 1, right; Clevers 2006). Both are required for canonical signaling. Ligand binding triggers phosphorylation of LRP5/6's cytoplasmic tail, creating an Axin-binding site. Axin recruitment inactivates the destruction complex, in a process requiring Disheveled (Dvl). This stabilizes $\beta$ cat, and it enters nuclei. $\beta$ cat displaces Groucho from TCF, nucleating formation of a multiprotein activator complex including Pygopus and Legless/Bcl9, activating Wnt target genes (Arce et al. 2006). The last 5 years have tested this proposed model, revealing new mechanistic insights and further complexity. In the following section, we examine different steps in Wnt signaling in turn and describe these new insights.

\section{PREPARING FOR DEPARTURE- POSTTRANSLATIONAL \\ WNT MODIFICATIONS}

After signal sequence cleavage and translocation into the endoplasmic reticulum (ER), Wnts are
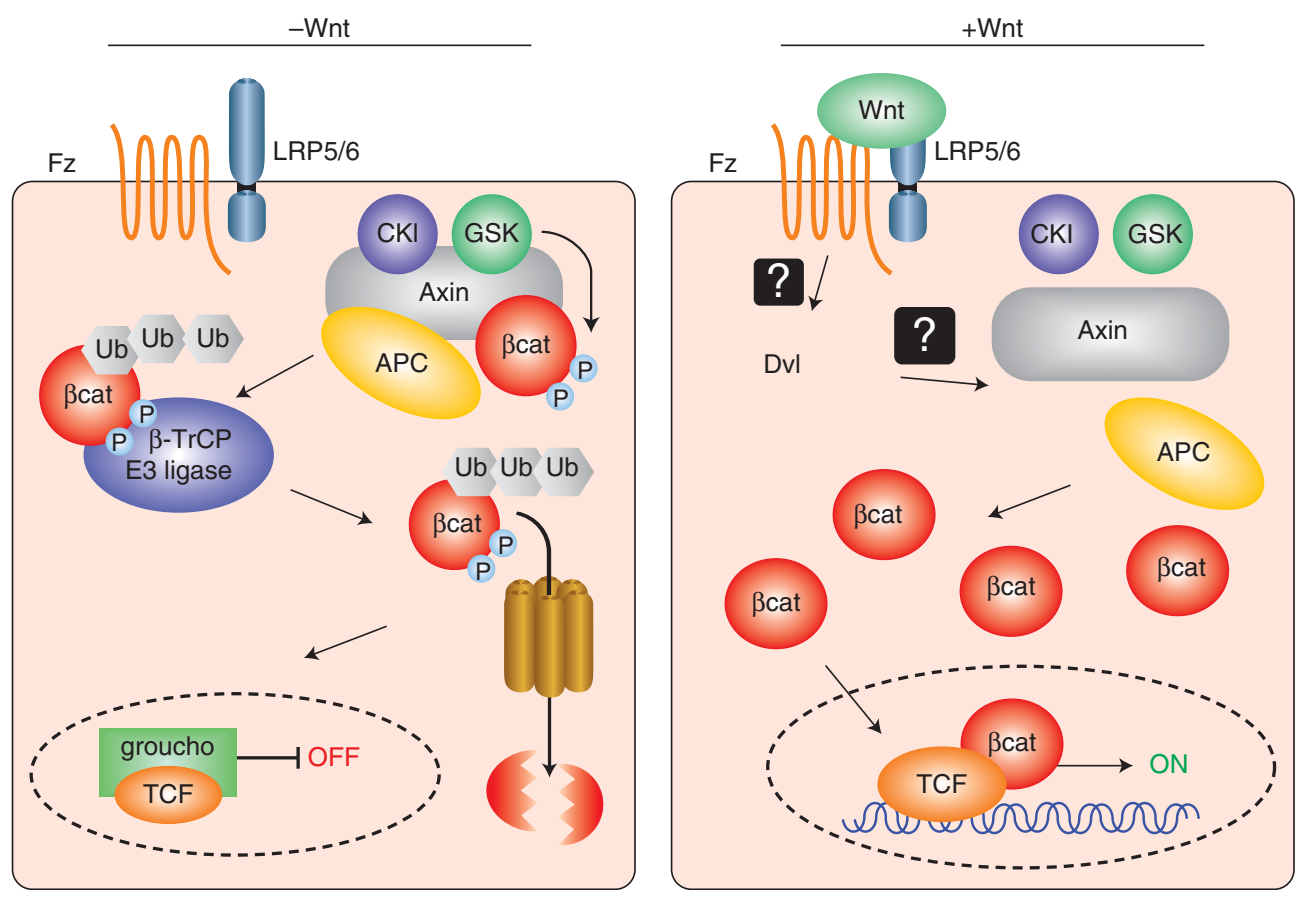

Figure 1. A simplified current view of Wnt signaling. See text for details. 
transported through the endomembrane system to the cell surface and undergo several modifications. Wnts undergo N-linked glycosylation (Burrus and McMahon 1995; Kadowaki et al. 1996; Komekado et al. 2007; Kurayoshi et al. 2007; Mason et al. 1992; Smolich et al. 1993; Tanaka et al. 2002). Several Wnts also are palmitoylated at the first conserved cysteine (Galli et al. 2007; Kadowaki et al. 1996; Komekado et al. 2007; Willert et al. 2003). In addition, Wnt3a is modified with palmitoleic acid at a conserved serine (Takada et al. 2006). These acylations likely cause the notoriously hydrophobic nature of secreted Wnts (Willert et al. 2003).

Posttranslational lipidation of mammalian Wnts is clearly important for function. Mutating the conserved cysteine of Wnt1, Wnt3a, or Wnt5a prevents palmitoylation in cell culture. These mutant Wnts are secreted but have little or no signaling activity (Galli et al. 2007; Komekado et al. 2007; Kurayoshi et al. 2007; Willert et al. 2003), and unpalmitoylated Wnts cannot bind $\mathrm{Fz}$ receptors (Komekado et al. 2007; Kurayoshi et al. 2007). Mutating the conserved serine in Wnt3a prevents palmitoleic acid addition and blocks secretion (Takada et al. 2006). These studies suggest a model in which palmitoleic acid-modification is required for secretion, and palmitate for Fz binding.

Research on Drosophila Wg confirms the importance of acylation, but results differ from those in mammals. For example, mutating the conserved serine in Wg to which palmitoleic acid is added in mouse Wnt3a does not prevent secretion, though it reduces signaling activity (Franch-Marro et al. 2008a). Wg is palmitoylated (Willert et al. 2003), and mutating this amino-terminal cysteine results in secreted but inactive Wg in cell culture (Franch-Marro et al. 2008a). However, the same mutant $\mathrm{Wg}$ accumulates in the ER in fly tissues (Franch-Marro et al. 2008a), and mutating this cysteine in the endogenous $w g$ gene prevents secretion (Nusse 2003). These data fit well with the porcupine (porc) phenotype, a strong loss of Wg signaling (van den Heuvel et al. 1993). Porc is an ER-localized integral membrane O-acyl transferase (Kadowaki et al.
Wnt Signaling from Development to Disease

1996) required for Wg palmitoylation (Zhai et al., 2004), and for Wg ER exit (Tanaka et al. 2002). Vertebrate Porc also promotes Wnt lipidation and is required for signaling (Galli et al. 2007). This suggests Porc acylates Wnts, though this has not yet been shown.

Apparent differences in palmitoylation's importance in Wnt signaling may reflect differences in levels of Wnt expression. In mammalian and fly cell culture, overexpression may overcome lack of palmitoylation. Consistent with this, whereas Porc is required for endogenous $\mathrm{Wg}$ signaling, it is not required when $\mathrm{Wg}$ is overexpressed (Noordermeer et al. 1994). In exploring relationships between Wnt glycosylation and lipidation, conflicting results were also obtained in culture versus in flies. Sitedirected mutagenesis of Wnt $3 \mathrm{a}$ and Wnt5a in cell culture suggested glycosylation precedes acylation and is required for ER export (Komekado et al. 2007; Kurayoshi et al. 2007). However, porc mutant fly embryos lacking acylation have defects in $\mathrm{Wg}$ glycosylation (Tanaka et al. 2002), suggesting acylation precedes glycosylation. While species or Wntspecific differences may explain these discrepancies, care must be taken in interpreting experiments in which Wnts are expressed at nonphysiological levels.

\section{GETTING OUT AND ABOUT - WNT SECRETION AND TRANSPORT}

For several Wnts, reaching the cell surface also requires Wntless (Wls) and Retromer. Wls (also known as Evi or Sprinter in flies and MIG-14 in Caenorhabditis elegans) is an integral membrane protein found in the Golgi, plasma membrane, and endosomes (Banziger et al. 2006; Belenkaya et al. 2008; Franch-Marro et al. 2008b; Port et al. 2008; Yang et al. 2008). Retromer is a multiprotein complex that shuttles cargo from endosomes to the trans-Golgi (Seaman 2005). Several recent reviews covered these proteins in detail (Bartscherer and Boutros 2008; Ching and Nusse 2006; Eaton 2008; Hardin and King 2008). In short, the data suggest Wls is a "Wnt chaperone," guiding Wnts from the Golgi to the cell surface. 
K.M. Cadigan and M. Peifer

Retromer mutants block Wnt secretion because Wls is missorted to lysosomes (Belenkaya et al. 2008; Franch-Marro et al. 2008b; Pan et al. 2008a; Port et al. 2008; Yang et al. 2008). Although this secretion mechanism is highly conserved, it is not universal. Drosophila WntD is secreted independently of lipidation, Porc, and Wls (Ching et al. 2008).

On secretion, Wnts move away from producing cells to influence neighbors (Cadigan 2002; Capdevila and Izpisua Belmonte 2001; Cayuso and Marti 2005; Strigini and Cohen 1999). One superb model for this is the Drosophila larval wing imaginal disc, a flat columnar epithelium. Wg is expressed along the dorsoventral $(\mathrm{D} / \mathrm{V})$ boundary and moves in both directions, forming a morphogen gradient and regulating short- and long-range targets in a concentration-dependent manner (Cadigan 2002; Strigini and Cohen 1999).
Wg can directly act up to 20 cell diameters from its synthesis site (Zecca et al. 1996).

Several factors influence Wg movement. Glypicans are heparin sulfate proteoglycans anchored to cell membranes via a glycerol phosphatidylinositol (GPI) linkage (Blair 2005). Two glypicans, Dally and Dally-like (Dly), influence Wg signaling in wing discs (Fig. 2). Dally promotes signaling and is suggested to facilitate Wg movement or act as a coreceptor (FranchMarro et al. 2005; Han et al. 2005). Interestingly, Dly has different functions than Dally. Loss of Dly increases expression of short-range targets but decreases long-range Wg signaling (FranchMarro et al. 2005; Han et al. 2005; Kirkpatrick et al. 2004; Kreuger et al. 2004). Consistent with this, dly mutants have reduced spread of Wg from its synthesis site (Han et al. 2005; Marois et al. 2006). A recent study suggests Dly mediates transcytosis of apically secreted

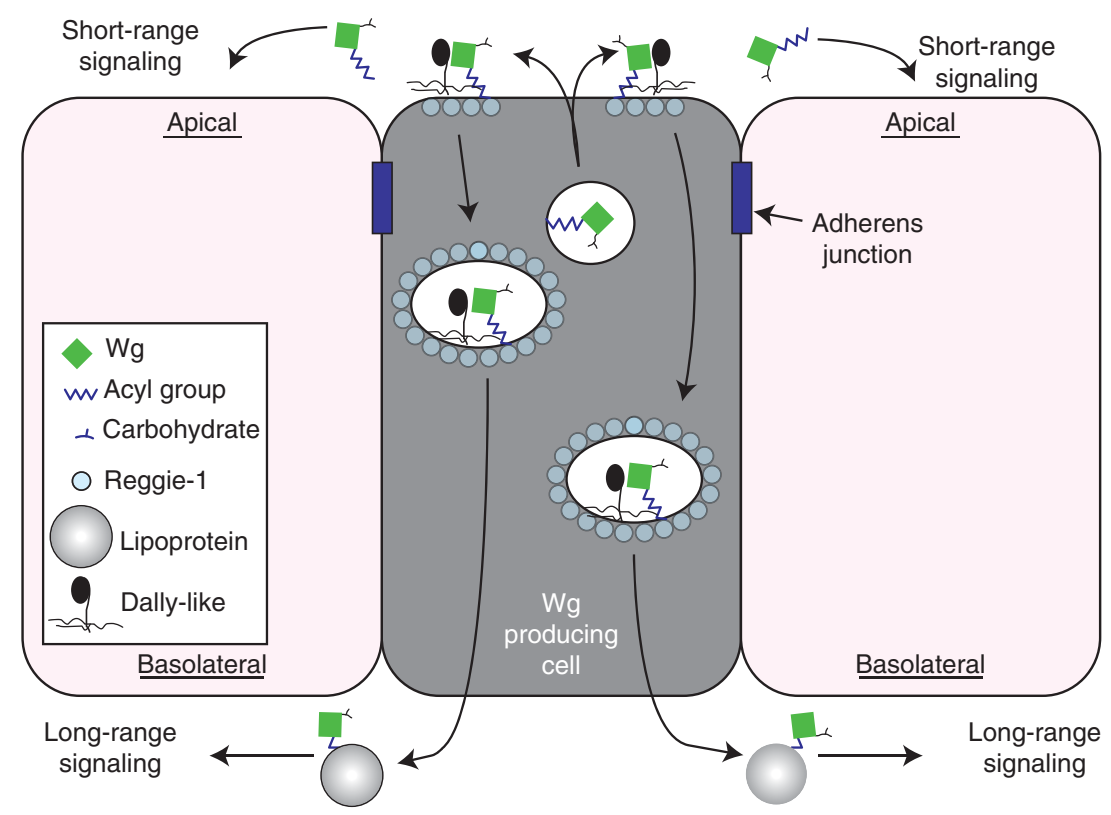

Figure 2. Model depicting Wg transcytosis and how this process could influence short- and long-range Wg signaling in the wing imaginal disc. Wg is secreted apically from producing cells, where association with extracellular glypican Dally-like directs it into endocytic vesicles. These Reggie-1-associated vesicles undergo transcytosis and fuse with the plasma membrane to release Wg on the basolateral side of the epithelial sheet. There, it can undergo long-range diffusion and signaling by associating with lipoproteins. See text for further explanation. 
Wnt Signaling from Development to Disease

$\mathrm{Wg}$, transporting it to the basolateral compartment (Gallet et al. 2008) where it then is presumed to diffuse to activate long-range targets.

Membrane microdomains also play roles in Wg secretion/diffusion (Katanaev et al. 2008). Reggie-1 (Flotillin-2) is a cytoplasmic component of noncaveolin lipid microdomains (Babuke and Tikkanen 2007; Langhorst et al. 2005). Reggie-1 loss strongly reduces longrange $\mathrm{Wg}$ targets but has no effect on shortrange targets (Katanaev et al. 2008). Conversely, Reggie-1 overexpression inhibits short-range and activates long-range targets, even when Reggie-1 expression is restricted to Wgexpressing cells. As Reggie-1 is implicated in vesicular trafficking (Babuke and Tikkanen 2007; Langhorst et al. 2008) and Wg can associate with lipid rafts (Zhai et al. 2004), these data suggest Reggie-1 works with Dly to promote $\mathrm{Wg}$ transcytosis and subsequent long-range diffusion (Fig. 2).

After transcytosis, how does $\mathrm{Wg}$ travel across wing discs? Several proteins participate. Wg can associate with lipoprotein particles, which are required for long-range signaling (Panakova et al. 2005). Endocytosis is proposed to be less efficient basolaterally, facilitating $\mathrm{Wg}$ diffusion (Marois et al. 2006). The Wg receptors $\mathrm{Fz}, \mathrm{Fz}-2$, and Arrow can promote Wg degradation (Han et al. 2005; Piddini et al. 2005), while the secreted hydrolase Notum can inhibit Wg signaling by modifying Dally and Dly (Giraldez et al. 2002; Han et al. 2005; Kirkpatrick et al. 2004; Kreuger et al. 2004).

It is not clear whether wing imaginal discs provide a general paradigm for Wnt transport. Even in the fly embryonic epidermis, where Wg signaling regulates cell fates (DiNardo et al. 1994), things may be different. Wg is internalized by secreting cells and recycled (Pfeiffer et al. 2002), consistent with transcytosis. However, while Dly is required for Wg signaling in this tissue (Franch-Marro et al. 2005), the inhibitory role evident in wing discs is not observed. Distinguishing general from tissuespecific mechanisms for transport of $\mathrm{Wg}$ and other Wnts remains an important goal.

\section{ACROSS THE PLASMA MEMBRANE- ASSEMBLING WNT SIGNALOSOMES}

Wnt/ $\beta$ cat signaling is generally mediated by two families of cell surface proteins: Fz family serpentine receptors, and lipoprotein receptorrelated proteins (LRP) mammalian LRP5 and LRP6 and fly Arrow (Arr) (Cadigan and Liu 2006; Gordon and Nusse 2006; $\mathrm{He}$ et al. 2004). Forced association of $\mathrm{Fz}$ and LRP/Arr activates Wnt/ $\beta$ cat signaling (Cong et al. 2004; Holmen et al. 2005; Tolwinski et al. 2003), consistent with reports that Wnt promotes Fz-LRP6 association in vitro (Tamai et al. 2000).

Wnt signaling also promotes phosphorylation of PPPSPxS motifs in LRP6's cytoplasmic tail by GSK3 and CKI (Tamai et al. 2004; Davidson et al. 2005; Zeng et al. 2005). LRP6 contains five PPPSPxP motifs and systematic mutagenesis revealed that all five contribute to signaling activity (MacDonald et al. 2008). Phosphorylated LRP6 recruits Axin to the plasma membrane, presumably inactivating the Axin-APC $\beta$ cat-destruction complex (Fig. 3) (Tamai et al. 2004; Zeng et al. 2005).

Wnt stimulation also induces LRP6 oligomerization into a large ribosome-size structure, termed the LRP6 signalosome (Fig. 3) (Bilic et al. 2007). Wnt induces phospho-LRP6 aggregates at the cell surface that colocalize with Dvls (Bilic et al. 2007), cytosolic proteins containing PDZ and DIX domains that are required for Wnt/ßcat signaling (Wallingford and Habas 2005; Wharton 2003). Intriguingly, Dvl forms microscopic puncta in cells (Roberts et al. 2007; Wharton 2003) that are recruited to the plasma membrane by Wnt signaling by interaction with Fzs (Cong et al. 2004; Wong et al. 2003). Dvl puncta are dynamic and form through interactions between two portions of Dvl DIX domains (Schwarz-Romond et al. 2007a). Dvl dimerization is not sufficient to activate Wnt/ $\beta$ cat signaling; instead, higher order oligomers are required (SchwarzRomond et al. 2007a). Although Dvl could not be detected in LRP6 signalosomes (Bilic et al. 2007), this may be because of its dynamic properties and instability in vitro. 
K.M. Cadigan and M. Peifer

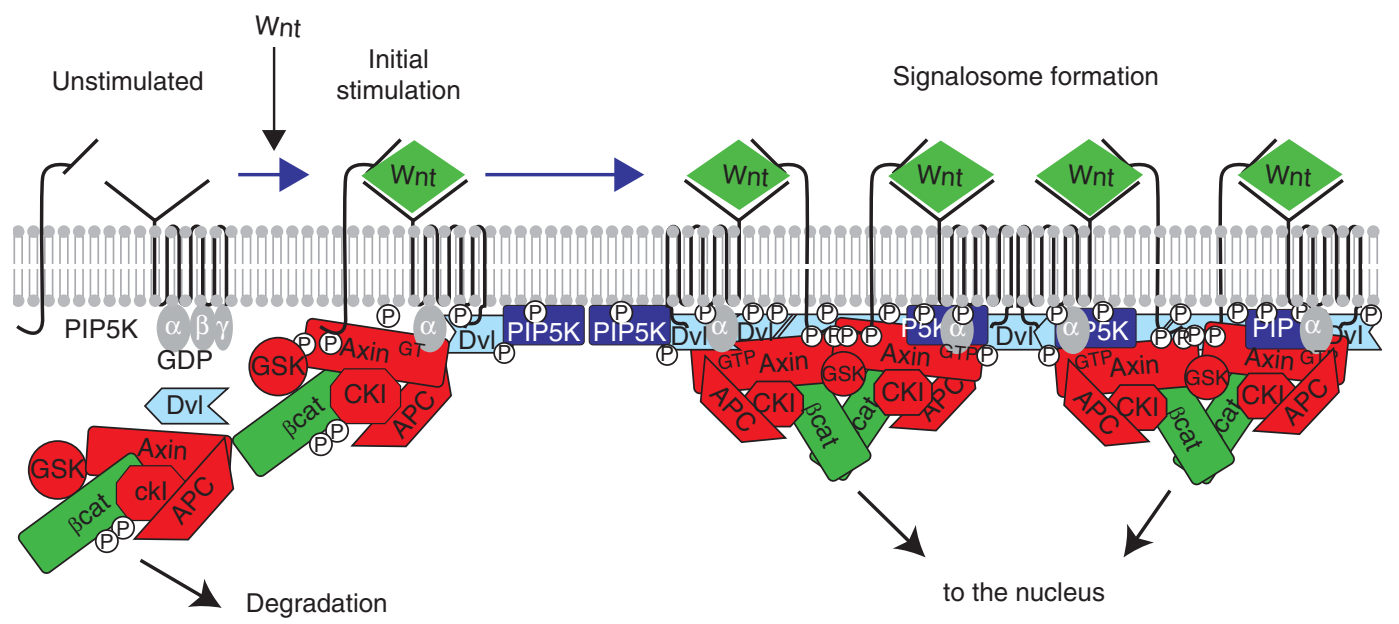

Figure 3. Model for the Wnt-induced formation of LRP5/6 signalosomes. In the absence of Wnt (at the left), LRP and Fz receptors are unassociated in the plasma membrane. Some data suggest that Fz may be coupled to trimeric G proteins, with the G $\alpha$ o subunit in the inactive GDP-bound form. PIPKII $\alpha$ (not shown for simplicity) and PIP5KI are membrane associated but inactive. The destruction complex (Axin, APC, GSK, and CKI) phosphorylates $\beta$ cat, tagging the protein for ubiquitination and proteosomal degradation (see text for further explanation). Initially, Wnt promotes association of LRP5/6 and Fz receptor, leading to phosphorylation of the cytoplasmic tail of LRP5/6 by CKI and GSK3 and recruitment of the destruction complex by binding to Axin. In addition, G $\alpha$ o is converted to its active GTP-bound form. One potential target of G $\alpha$ o-GTP is Dvl, which is recruited to the receptor complex, where it can bind and activate PIP5KI, causing an increase in PIP2. All of these modifications appear to reinforce each other in a complex positive feedback loop, leading to a large complex of Wnt, LRP5/6, Fz, Dvl, and degradation complex at the cell surface. GSK activity is inhibited by interaction with the LRP phosphorylated tail, resulting in the accumulation of hypophosphorylated $\beta$ cat, which can then translocate to the nucleus. See text for more details.

However, imaging studies in living cells support a model in which Wnt induces a large plasma membrane complex of phospho-LRP, Fz, and Dvl.

Axin is found in LRP signalosomes (Bilic et al. 2007), consistent with phospho-LRP binding Axin (Tamai et al. 2004; Zeng et al. 2005). GSK3 is also in signalosomes (Bilic et al. 2007) and Axin is required for LRP phosphorylation (Zeng et al. 2008). This suggests signalosome formation is not strictly linear. Rather, LRP phosphorylation initially recruits Axin, bringing additional GSK3 to promote more LRP phosphorylation. This positive feedback loop may be important in signalosome formation (Fig. 3); consistent with this, Dvl puncta can recruit Axin and CKI (SchwarzRomond et al. 2007b). In Drosophila, biochemical evidence for Arrow signalosomes has not yet been reported. Analysis of chimeric Arrow receptors argues for distinct initiation and amplification steps in $\mathrm{Wg}$ signaling (BaigLewis et al. 2007), which could be consistent with the vertebrate model (Fig. 3).

A recent report added to the complexity of LRP6 signalosomes (Pan et al. 2008b). siRNA screening revealed that phosphatidylinositol 4-kinase type II $\alpha$ (PI4KII $\alpha$ ) and phosphatidylinositol-4-phosphate 5-kinase type I (PIP5KI) are required for Wnt-induced LRP-phosphorylation and $\beta$ cat accumulation in culture, and Wnt/ $\beta$ cat signaling in Xenopus (Pan et al. 2008b). PI4KII and PIP5KI produce phosphatidylinositol (4,5)bis-phosphate (PIP2) (Doughman et al. 2003), and delivery of PIP2 to cells stimulated Wnt signaling, whereas PIP2 depletion reduced LRP-phosphorylation by Wnt (Pan et al. 2008b). Wnt stimulation also increased PIP2 formation. This was Dvl-dependent, and recombinant Dvl activates 
PIPKI in vitro, suggesting a new role for Dvl. PIP2 is required for LRP6 signalosome formation, and PIP2 is enriched in fractions containing signalosomes (Pan et al. 2008b). This provides strong evidence for PI kinases and PIP2 in Wnt receptor function (Fig. 3).

If Dvl binds and activates PIP5KI, how is Dvl activated by Wnt signaling? One possibility is through Fz-mediated $\mathrm{G}$ protein signaling. Studies in both mammalian cell culture (Liu et al. 2005) and Drosophila (Katanaev et al. 2005) suggest $\mathrm{G} \alpha \mathrm{o}$ is required for $\mathrm{Wnt} / \beta \mathrm{cat}$ signaling. This requirement is upstream of Dvl (Katanaev et al. 2005), suggesting a model in which information is passed from $\mathrm{Fz}$ to $\mathrm{G} \alpha \mathrm{o}$ to Dvl (Fig. 3).

How do LRP signalosomes promote $\beta$ cat accumulation? Wnt stimulation or LRP overexpression decrease Axin protein levels in several systems (Kofron et al. 2007; Mao et al. 2001; Tolwinski et al. 2003), which should compromise the destruction complex. LRP-mediated Axin down-regulation and inhibition of $\beta$ cat degradation can be recapitulated in vitro, but LRP still stabilizes $\beta$ cat when endogenous Axin is replaced with a nondegradable version (Cselenyi et al. 2008). LRP's phosphorylated tail can directly inhibit GSK3 activity (Cselenyi et al. 2008; Piao et al. 2008), which may contribute to destruction complex inhibition. Consistent with this, dephosphorylated $\beta c$ at and APC are recruited to the plasma membrane on Wnt signaling (Hendriksen et al. 2008). Interestingly, dephosphorylated $\beta$ cat generated by LRP6 activation is much more potent (molecule for molecule) at activating Wnt target genes than overexpressed nonphosphorylatable $\beta$ cat (Hendriksen et al. 2008 ); thus, additional $\beta$ cat activation events may occur on receptor activation.

LRP signalosomes also colocalize with Caveolin-1, a caveolae marker (Bilic et al. 2007). Functional connections between Wnt/ $\beta$ cat signaling and Caveolin-1 were reported, suggesting that caveolae-induced endocytosis of LRP6 is required for signaling (Yamamoto et al. 2006). However, caveolin-1, caveolin-2, and caveolin-3 knockouts are all viable, as are caveolin-1 caveolin-3 double knockouts (Le Lay and
Wnt Signaling from Development to Disease

Kurzchalia 2005), suggesting that they do not play essential roles. In fact, caveolin-1 mutants were reported to have increased Wnt/ $\beta$ cat signaling (Sotgia et al. 2005). Drosophila lacks recognizable Caveolins (Le Lay and Kurzchalia 2005), suggesting that caveolae are not essential for $\mathrm{Wg}$ signaling.

\section{IF IT IS IN THE TEXTBOOK, WHY ARE YOU STILL STUDYING IT?}

The canonical model for Wnt regulation was an important advance, and is widely accepted and incorporated into cell biology textbooks. However, this overstates our knowledge of how things actually work: Many key questions remain. Given that Axin, which binds numerous partners, is likely the scaffold for destructioncomplex assembly, APC's mechanistic role remains mysterious. Second, it is not clear where the destruction complex resides, or whether its localization changes on Wnt signaling to modulate inactivation. Third, the detailed biochemical interactions modulating $\beta$ cat phosphorylation and release to the E3 ubiquitin-ligase remain to be elucidated. Finally, the multiple APC and Axin family members in many animals raise questions about differential function or redundancy.

With the realization that Axin is the scaffold for destruction-complex assembly, the search began for other APC mechanisms of action. One model is that APC helps localize the destruction complex to the correct location (Fig. 4A). There has been substantial difficulty in localizing endogenous Axin, though if overexpressed it forms large cytoplasmic puncta. GSK3 and CKI both accumulate throughout cells, reflecting their many substrates. Thus, the clearest picture came from studying APC. Both mammalian APC (Näthke et al. 1996) and Drosophila APC2 (McCartney et al. 1999; Yu et al. 1999) are enriched at the cortex of epithelial cells, suggesting this may be the normal location of the destruction complex. Consistent with this, missense mutations in fly APC2 exhibit a strong correlation between loss of cortical protein localization and loss of function in Wnt regulation (McCartney et al. 2006). 
K.M. Cadigan and M. Peifer

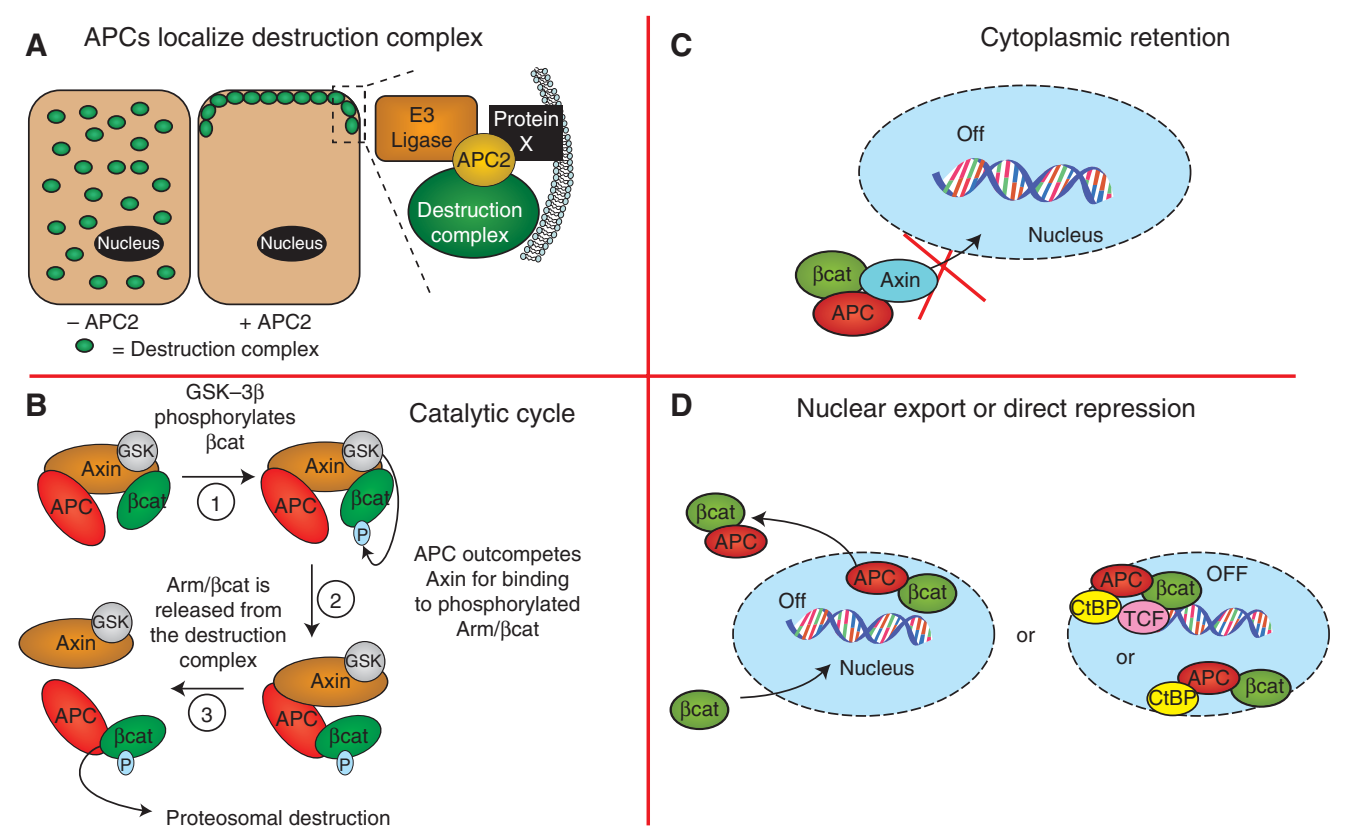

Figure 4. Four proposed models for the role of APC in the destruction complex. (A) APC binds the destruction complex and unknown protein $\mathrm{X}$, recruiting the destruction complex to the apical cell cortex and connecting it to the E3 ubiquitin ligase. $(B)$ The catalytic cycle model in which $\beta$ cat is sequentially bound to Axin and then APC before transfer to the E3 ligase. $(C)$ Cytoplasmic retention model. Axin and APC bind cytoplasmic $\beta$ cat and tether it there. $(D)$ APC in nucleus. APC exports $\beta$ cat from nucleus or acts directly at promotors in transcriptional repression. See text for more details.

The apical cortex is attractive, as it brings APC into proximity of at least a subset of Fz receptors (Wu et al. 2004).

However, other data is less consistent with this model. Although fly APC1 and APC2 are redundant in many tissues (Ahmed et al. 2002; Akong et al. 2002a), their intracellular localizations are quite distinct. APC1 localizes to axons in neurons, and to centrosomes and microtubules when overexpressed (Akong et al. 2002a; Akong et al. 2002b; Hayashi et al. 1997). APC1 and APC2 have similar differential localization in male germline stem cells (Yamashita et al. 2003). How do we explain this? Possibilities include: (1) Each APC localizes to the other location at lower but still functional levels, (2) The destruction complex can function at several locations, or (3) APC does not localize the destruction complex. Overexpressed Axin recruits APC to cytoplasmic puncta (e.g., Faux et al. 2008), perhaps consistent with the latter conclusion, but colocalization of endogenous APC and Axin is difficult to detect. It is also important to remember that APC proteins have Wnt independent cytoskeletal functions (Näthke 2006), and thus many of the sites where APC proteins localize, including their predominant localization sites, may reflect these cytoskeletal functions rather than the localization of the destruction complex.

Strikingly, in C. elegans, localization of Wnt signaling proteins during Wnt-mediated asymmetric divisions suggests a different way of wiring the pathway (Mizumoto and Sawa 2007; Takeshita and Sawa 2005). Apr-1 (APC), Pry-1 (Axin), and Dvl homologs all localize to the cortex, and do so asymmetrically. Surprisingly, Wrm- $1 / \beta$ cat acts at the cortex to inhibit Wnt signaling, a striking reversal of canonical signaling, whereas cortical Apr-1 mediates nuclear "export" of Wrm-1 (these data might also be explained by cytoplasmic Wrm-1 retention). Thus, natural selection can 
Wnt Signaling from Development to Disease

reshape even this highly conserved pathway; similar asymmetries may occur in other animals (Schneider and Bowerman 2007).

\section{REGULATING $\beta$ CAT DESTRUCTION IS A COMPLEX TOPIC}

Other models for APC function arose from structural/biochemical studies. The Weis and $\mathrm{Xu}$ laboratories examined affinities of $\beta$ cat for both APC and Axin (Choi et al. 2006; Ha et al. 2004; Liu et al. 2006; Xing et al. 2003). The results were intriguing. Under basal conditions, $\beta$ cat's affinity for Axin is higher than that for APC. However, if APC is phosphorylated by GSK3 within the $\beta$ cat-binding 20amino acid (aa) repeats, APC has a higher affinity for $\beta$ cat than Axin. This led Kimelman and $\mathrm{Xu}$ (2006) to propose that the destruction complex goes through a cycle of structural rearrangements (Fig. 4B). It assembles with Axin bound to $\beta$ cat, because of its higher affinity. $\beta$ cat and APC are both phosphorylated by GSK3, triggering transfer of $\beta$ cat to APC. This is suggested to facilitate $\beta$ cat transfer to the E3 ubiquitin ligase, with presumed APC dephosphorylation by $\mathrm{PP} 2 \mathrm{~A}$ resetting the system. This is an intriguing model, which can be tested by site-directed mutations in APC.

In contrast, Weis' laboratory interpreted their data differently. They directly showed that Axin can be a scaffold for substrate phosphorylation (Ha et al. 2004). However, phosphorylated APC bound to $\beta$ cat is not accessible to dephosphorylation (albeit by PP1, not PP2), inconsistent with the catalytic cycle model. They suggest that altered APC affinity for $\beta$ cat allows it to accommodate drastically different $\beta$ cat levels in the presence or absence of Wnt signal.

Recent data support a role for APC in facilitating transfer of phospho- $\beta$ cat to the E3 ubiquitin ligase ( $\mathrm{Su}$ et al. 2008). In a cell-free system, extracts from APC mutant colon cancer cells can phosphorylate but not ubiquitinate $\beta$ cat, consistent with Axin playing the primary scaffolding role. Adding tagged APC restores ubiquitination. Added APC also restores the ability of phospho- $\beta$ cat to coIP with $\beta$ TrCP. Finally, APC can protect phospho- $\beta$ cat from dephosphorylation. These results are quite interesting, and suggest transferring $\beta$ cat from the destruction complex to the E3 ligase is an important APC role.

\section{DECONSTRUCTING THE DESTRUCTION COMPLEX}

Full mechanistic understanding requires dissecting the moving parts of the destruction machine. Several laboratories did so. Wehrli's laboratory examined Axin's mechanism of action by site-directed mutagenesis and analysis in vivo in Drosophila (Peterson-Nedry et al. 2008). Their results were quite surprising. Substantial Axin function was retained by proteins lacking binding sites for APC (the RGS domain) or for $\beta$ cat. Even Axin lacking the GSK3 binding site retained some function. These data suggest that the destruction complex is stabilized by multiple interactions, with individual protein contacts somewhat dispensable. Strikingly, mutants lacking the PP2A binding site or Dix domain had phenotypes suggesting that these mutant proteins could not be turned off by Wnt signaling, consistent with proposed roles for PP2A and Dvl in inactivating the destruction complex. Finally, an Axin mutant lacking the $\beta$ cat binding site was complemented in trans by one lacking the APC binding site, suggesting that the functional destruction complex contains multiple copies of Axin.

APCs are also complex mosaics (Näthke 2006; Polakis 2007). All share core domains that together are sufficient for Wnt regulation: Arm repeats, 15- and 20-aa repeats that bind $\beta c a t$, and SAMP repeats that bind Axin. Many APCs also carry carboxy-terminal extensions, allowing interactions with microtubules, the microtubule plus-end binding protein EB1, and other partners, presumably modulating cytoskeletal functions. Colon tumors carry truncated APC proteins lacking a subset of $\beta$ cat binding sites and all the Axin-binding SAMP repeats (Polakis 1995). In mice, a truncated APC lacking the cytoskeletal-interacting carboxyl terminus but retaining one SAMP 
motif still regulates Wnt signaling (it is homozygous viable) (Smits et al. 1999). In contrast, loss of 65 additional amino acids abrogated Wnt signaling. This complemented earlier work in cultured colon cancer cells, which also suggested key roles for 20-aa and SAMP repeats (Munemitsu et al. 1995; Rubinfeld et al. 1997).

All APCs share amino-terminal Arm repeats (Peifer et al. 1994), known binding sites for several protein partners (Näthke 2006). In Drosophila APC2, the Arm repeats play key roles in Wnt signaling (McCartney et al. 2006; Hamada and Bienz 2002; McCartney et al. 1999). Both the Arm repeats and the region including the 20-aa and SAMP repeats are important for APC2's cortical localization (McCartney et al. 2006), supporting the hypothesis that APC2 acts at the cortex in Wnt regulation and suggesting the existence of an unidentified cortical partner.

Two APC2 alleles precisely mimic truncations in human tumors (Polakis 2007), allowing testing of hypotheses concerning roles of truncated proteins. Some suggested that they have dominant-negative effects on Wnt signaling or chromosome segregation, and it remained unclear whether they are null for Wnt regulation. Phenotypic comparisons with the null allele revealed that truncated APCs are severely impaired but not null for Wnt signaling. They do not have dominant-negative effects on Wnt signaling, although they can have dominantnegative effects on cytoskeletal events (McCartney et al. 2006). These data support the "just-right" hypothesis (Albuquerque et al. 2002), suggesting that selection during development of colon polyps favors mutations that reduce but do not eliminate APC regulation, producing just the right level of Wnt signal.

Behrens' laboratory explored possible roles of another conserved sequence they term the CID (Kohler et al. 2009), using a cultured cell assay pioneered by Polakis (Munemitsu et al. 1995; Rubinfeld et al. 1997). To their surprise, truncated APC lacking all SAMP repeats substantially rescued $\beta$ cat regulation, in contrast to what is seen in mice (Smits et al. 1999). Instead, they saw a sharp drop in rescuing ability when they removed the CID, a sequence conserved in both insect and both mammalian APCs. As the authors point out, these data are somewhat paradoxical, because some colon tumors carry truncated APCs retaining CID. They find that different colon cancer cell lines differ in their ability to be rescued by SAMP-less fragments, suggesting that differences at other loci are important. These data also reinforce the idea that multiple protein interactions are likely important to assemble a functional destruction complex.

\section{APC IN AND OUT OF NUCLEI}

Although regulating $\beta$ cat stability is critical for Wnt signaling, some data suggest additional roles for APC and Axin in Wnt regulation. One early, plausible suggestion was that the destruction complex is also a cytoplasmic anchor for $\beta$ cat, reducing activation of Wnt target genes (Fig. 4C) (Tolwinski and Wieschaus 2001). Wieschaus' laboratory found that Wnt signaling alters Axin stability, thus regulating its cytoplasmic anchoring function (Tolwinski et al. 2003). Others provided evidence for an anchoring role for APCs (Ahmed et al. 2002; Akong et al. 2002a; Krieghoff et al. 2006). It seems likely that cytoplasmic retention plays an important modulatory role, working together with targeted destruction.

Others suggested APC acts in other cellular compartments. Nuclear localization and export signals on APC led to the suggestion that it regulates $\beta$ cat nuclear export (Fig. 4D) (reviewed in Brocardo and Henderson 2008). Two papers support an even more direct role for APCs in nuclei (Fig. 4D). Hamada and Bienz (Hamada and Bienz 2004) identified interactions between APC and the transcriptional repressor (carboxy-terminal binding protein $[\mathrm{CtBP}])$ by proteomics. They argue that nuclear CtBP, by binding APC and thus indirectly recruiting $\beta c a t$, is a nuclear $\beta$ cat sink (see Fig. 5), reducing TCF association and thus reducing Wnt-regulated transcription. Even more direct action is envisioned by Jones' laboratory (Sierra et al. 2006). APC can be ChIPed at the Wnt target gene c-myc. 
Strikingly, it binds there with $\beta \operatorname{TrCP}$ and CtBP. They suggest that transient APC recruitment leads to long-term repression, and argue that carboxy-terminally truncated APCs in colon tumors, which no longer interact with CtBP, are impaired in this. These possible direct roles for APC in repressing $\beta$ cat-driven transcription are intriguing. However, activating $\beta$ cat mutants, lacking single phosphorylation sites and thus not targeted for destruction, can cause colorectal and other cancers (Polakis 2007), suggesting that regulating $\beta$ cat stability is APC's primary role, with other roles likely to be modulatory.

\section{DOUBLE THE FUN}

Questions about APC function are further complicated by the two family members in mammals (APC and APC2) and Drosophila (APC1 and APC2). All four regulate $\beta$ cat stability, so their shared core domains must be sufficient for this. Fly APC1 negatively regulates Wnt signaling in the eye (Ahmed et al. 1998), whereas fly APC2, which is more broadly expressed, regulates Wnt signaling in the embryonic epidermis (McCartney et al. 1999). However, in many tissues, they are functionally redundant (Ahmed et al. 2002; Akong et al. 2002a). Further, even in tissues in which one has the predominant role, removing the other enhances Wnt activation (Akong et al. 2002a; Benchabane et al. 2008). This argues that even low levels of APC, near the detection threshold, confer residual function. Redundancy among mammalian APCs could explain why APC mutants are found only in colorectal tumors and not other tumors in which Wnt activation is implicated (Polakis 2007); however, the lack of published mouse APC2 mutants precludes this analysis.

Exploring functions of the two fly APCs led to further insights (Takacs et al. 2008). In screening for mutations suppressing the APC1 eye phenotype, Ahmed's laboratory obtained APC2 alleles. This was surprising, because in other contexts the two APCs act redundantly, and suggests that APCs play positive as well as negative roles in Wnt signaling. Their data
Wnt Signaling from Development to Disease

further suggest that APC can promote Axin turnover, likely in response to Wnt signals, and suggest that this requires the Arm repeats, while the carboxy-terminal region is dispensable. These striking findings remind us that feedback regulation is likely to play a role in signaling. The mechanism for targeting Axin for proteolysis remains to be determined. The HECT domain E3 ubiquitin-ligase Edd binds to APC, but stabilizes rather than destabilizes Axin and APC (Ohshima et al. 2007) suggesting even more complexity in feedback regulation.

There are also two mammalian Axins, with presumed functional overlap. Axin loss leads to early embryonic lethality (Zeng et al. 1997). Axin2/Conductin mutants are viable with craniofacial defects in mice (Yu et al. 2005) and human patients (Lammi et al. 2004). Chia and Constantini (2005) tested functional equivalence by knocking Axin2 into the Axin locus; this resulted in a viable, normal mouse. Flies have only a single Axin, which is essential for Wnt regulation (Hamada et al. 1999; Willert et al. 1999). In contrast, C. elegans also has two Axins. Both diverged dramatically from mammalian and fly Axins, retaining only recognizable RGS and Dix domains (Korswagen et al. 2002; Oosterveen et al. 2007). The two worm Axins functionally overlap; axl-1 mutations enhance many pry-1 phenotypes, while Axl-1 has phenotypes in some tissues unaffected by Pry-1 loss. The reduced sequence similarity and altered protein interactions call into question the universality of mechanisms of regulating $\beta$ cat.

\section{AND IF THAT WAS NOT COMPLEX ENOUGH, LET US ADD NEW PLAYERS}

Recent work identified several other potential Wnt regulators. One is Wtx/Amer, originally identified as a gene mutated in renal Wilms tumors (Rivera et al. 2007). Other Wilms tumors have activating mutations in $\beta$ cat (Koesters et al. 1999), suggesting that Wnt signaling plays a role in pathogenesis. Two recent papers independently connected Wtx to Wnt signaling. Moon's laboratory used proteomics to identify new partners of $\beta$ cat, APC, and 
Axin (Major et al. 2007). Among them was Wtx, which bound all three TAP-tagged baits. Wtx can also interact directly with $\beta \operatorname{TrCP}$, suggesting that it might help bridge the destruction complex and E3 ligase. In vivo assays in Xenopus supported a role in negative Wnt regulation. However, changes in $\beta$ cat stability and Wnt pathway activation were milder than those caused by loss of core components of the destruction machinery.

In parallel, Behrens' laboratory identified Wtx (they refer to it as Amerl) in a two-hybrid screen for proteins interacting with APC's Arm repeats (Grohmann et al. 2007). Wtx can recruit APC to the plasma membrane, perhaps by binding PIP2, and Wtx positively regulates APC stability. These two datasets are distinct but consistent-stabilizing APC would promote $\beta$ cat destruction. However, much more remains to be learned about Wtx function. Wtx has a second vertebrate paralog, which might explain the relatively modest effects of knockdown in Xenopus and the presence of Wtx mutations in Wilms' but not other tumors (Yoo et al. 2008). Surprisingly, however, there are no Wtx homologs in flies or worms, suggesting that it is not a universal part of the pathway.

Another possible vertebrate-specific Wnt regulator is the cytoskeletal protein MCAF, which cross-links actin, intermediate filaments, and microtubules. MACF1 mutant mice are embryonic lethal (unlike its paralog BPAG, which has postnatal neural defects) (Chen et al. 2006). Although $M A C F$ embryos do not die until E11.5, they arrest at E7.5, and lack mesoderm and the primitive streak. The phenotype is similar to that of Wnt3a or LRP $5+6$ knockouts, though marker analysis in the MACF study is relatively limited. MACF1 can coIP with Axin, APC, $\beta$ cat, and GSK3, suggesting that it associates with the destruction complex, and that MACF1 siRNA blunts Wnt3-induced transcription and reduces $\beta$ cat levels. MACF1 also coIPs with LRP5/6, suggesting a possible role in destruction complex inactivation. Consistent with this, MACF1 knockdown reduces Axin recruitment to the membrane after Wnt treatment. It will be interesting to further examine phenotypic similarities and differences between MACF1 and other key Wnt pathway proteins. The lack of reported Wnt phenotypes of mutations in Shortstop, the fly homolog, suggest that MACF1's role in Wnt signaling may also be vertebrate-specific.

Bejsovec's laboratory discovered another novel negative regulator, Rac-GTPase-activatingprotein RacGAP50C, in screening for modifiers of Drosophila wg mutants (Jones and Bejsovec 2005). It may act in synergy with Naked cuticle (Nkd). RacGAP50C has a known role in cytokinesis (Gregory et al. 2008; Zavortink et al. 2005), but its role in Wnt signaling is independent of this, and, surprisingly, independent of GAP activity. The mechanism by which RacGAP50C acts, and whether its mammalian homolog regulates Wnt signaling remain to be determined.

Nkd and its mammalian homologs also may differ in their importance in flies and mammals. Both bind Dvl (e.g., Rousset et al. 2001; Wharton et al. 2001), but their function is unknown. Fly Nkd is a key negative regulator (Zeng et al. 2000), although signaling is not activated to quite the same degree as is seen on complete destruction complex inactivation. Overexpressing zebrafish Nkd homologs suppresses both canonical and noncanonical Wnt signaling (Van Raay et al. 2007). Surprisingly, however, $N k d 1$ and $N k d 2$ single mutant mice and even $N k d 1$ Nkd2 double mutants are viable and relatively normal (Zhang et al. 2007). Double mutants have subtle cranial abnormalities like those of Axin2. Thus, Nkd is a relatively minor modulator of mammalian Wnt signaling.

\section{INTO THE NUCLEUS - TARGET GENE REGULATION BY $\beta C A T / A R M$}

On entry into the nucleus, stabilized $\beta$ cat/Arm transcriptionally regulates Wnt target genes. However, $\beta$ cat/Arm cannot bind DNA. Rather, it is a coregulator, binding to transcription factors. Members of the TCF family of high mobility group (HMG) DNA-binding proteins are responsible for much of this regulation. Flies and worms have only one TCF (TCF/Pangolin 
Wnt Signaling from Development to Disease

and POP-1, respectively). Mammals have four TCFs (TCF1, Lef-1, TCF-3, and TCF-4). In addition to TCFs, several other transcription factors can recruit $\beta$ cat to target genes, including mouse PitX1 (Kioussi et al. 2002), Xenopus SOX17 (Sinner et al. 2004), and C. elegans FOXO-1 (Essers et al. 2005). Here, we focus on the mechanism by which $\beta$ cat/Arm regulates transcriptional activity of TCFs.

TCFs are thought to be bimodal regulators of Wnt targets (Fig. 5). In the absence of signal, they act with corepressors to keep Wnt target genes silenced. $\beta$ cat/Arm binding to TCF antagonizes this repression and recruits additional coactivators, inducing target gene expression. Thus, TCF is a transcriptional switch, with $\beta$ cat/Arm converting repression to activation (reviewed in Parker et al. 2007; Stadeli et al. 2006; Willert and Jones 2006).

TCFs recognize specific DNA sequences through their HMG domains (Laudet et al. 1993). Several studies of different TCFs largely agree that CCTTTGAT is a high affinity site for the HMG domain (Barolo 2006). However,

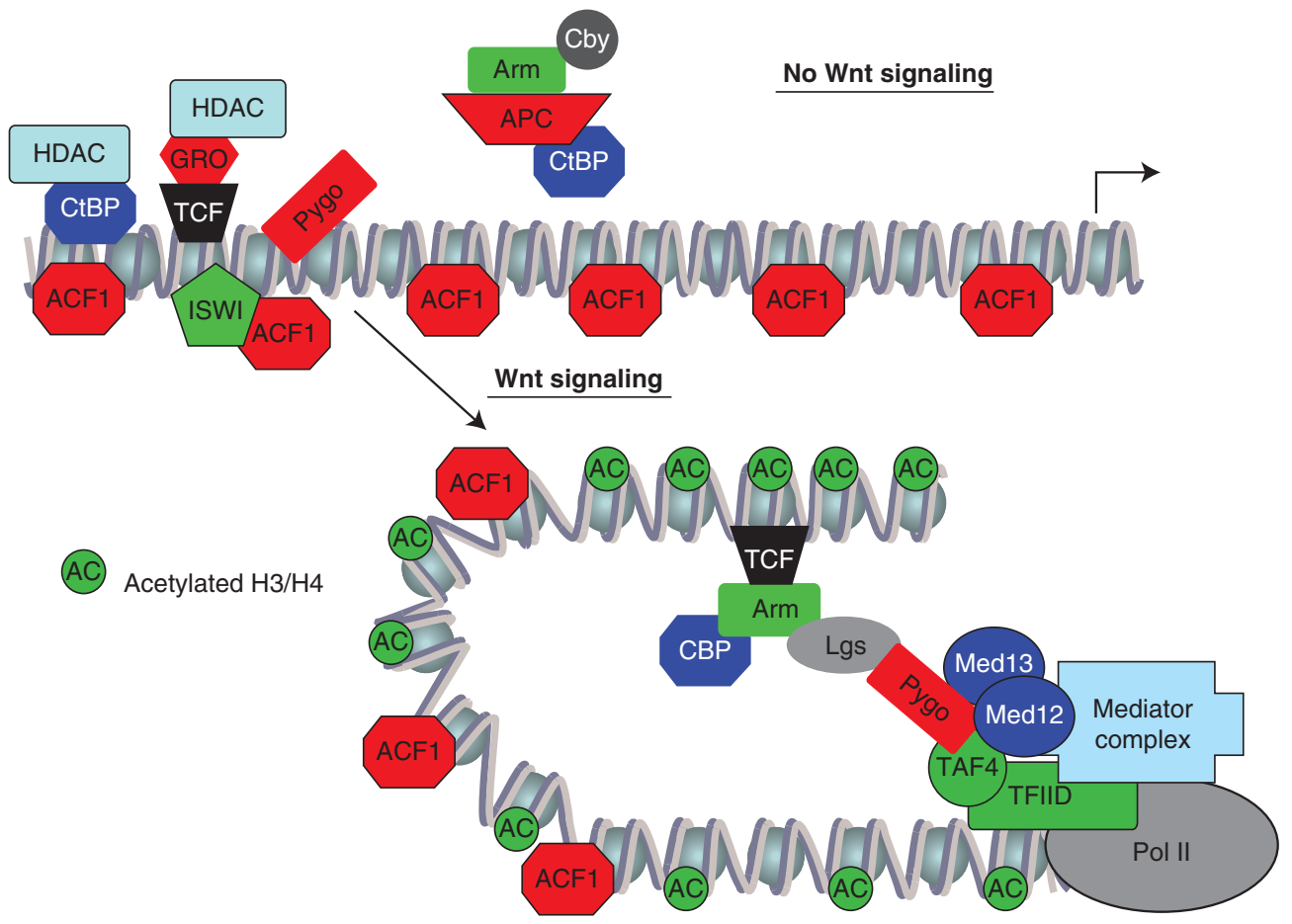

Figure 5. Model for target gene regulation by Wg signaling in Drosophila. The top part of the figure outlines some of the mechanisms by which target genes are repressed in the absence of Wg signaling. TCF recruits Gro through direct binding, while CtBP is recruited to WREs in an TCF-independent manner. Both corepressors may act by recruiting HDACs. In addition, the ISWI-ACF1 is recruited to the WRE in a TCF-independent way. Although ISWI remains near the WRE, ACF1 spreads across the loci. Low levels of nuclear Armadillo (Arm) are diverted away from TCF by an APC-CtBP complex or Cby. When high levels of Arm accumulate in the nucleus after Wg signaling, Arm binds to TCF, displacing Gro and recruiting additional coactivators. For simplicity, only two are shown in the bottom part of the figure. The histone acetyltransferase CBP is recruited by the carboxy-terminal Arm transactivation domain and causes a widespread increase in histone acetylation at Wg target loci. ISWI and ACF1 are bound less efficiently to acetylated histone chromatin. The amino-terminal transactivation domain of Arm recruits Lgs and Pygo. Pygo then contacts the Med12 and Med13 subunits of the mediator complex, as well as the TAF4 subunit of the TFIID basal transcription complex. Thus, Pygo acts as an adaptor, connecting the TCF activation complex with the basal transcription machinery to activate target gene expression. 
TCF can also bind motifs differing from this consensus (Hallikas et al. 2006). In addition, several Wnt response elements (WREs) in flies have functional TCF-binding sites varying significantly from the consensus (Chang et al. 2008a; Lee and Frasch 2000; Riese et al. 1997). Given the degeneracy of DNA recognition by TCF, potential binding sites are found with high frequency throughout the genome. This suggests that additional sequence information may exist to specify which TCF sites can act as WREs.

For some TCFs, an additional DNA-binding domain was recently shown to provide greater DNA-binding specificity. Some mammalian TCF isoforms (TCF-1E and TCF-4E) contain an additional motif carboxy-terminal to the HMG domain, allowing them to bind an extended DNA sequence (Atcha et al. 2007). This 30-residue motif-the C-clamp-is highly conserved in invertebrate TCFs (Atcha et al. 2007). The extended sequence it binds ( $\mathrm{RCCG} ; \mathrm{R}=\mathrm{A}$ or $\mathrm{G}$ ) resembles the sequence of "TCF helper sites" (GCCGCCR), recently discovered in several fly WREs, where they are as essential for Wnt responsiveness as classic TCF-binding sites (Chang et al. 2008b). These WREs require the TCF C-clamp for activation, and in vitro DNA binding studies suggest fly TCF binds in a bipartite manner, with the HMG domain binding the classic site and the C-clamp binding the Helper site (Chang et al. 2008b). This mechanism appears to be essential in flies (where all major TCF isoforms contain a C-clamp) and raises the question of how vertebrate TCFs lacking a C-clamp efficiently locate their targets.

In the absence of Wnt stimulation, TCF is thought to silence target gene expression by recruiting corepressors (Fig. 5). TCFs can bind TLE/Groucho/Grg family corepressors (Cavallo et al. 1998; Daniels and Weis 2005; Roose et al. 1998). Flies only contain one family member (Groucho), which clearly contributes to silencing in the absence of Wnt signaling (Cavallo et al. 1998; Fang et al. 2006; Mieszczanek et al. 2008). TLE and $\beta$ cat compete for binding to TCF (Daniels and Weis 2005). Consistent with this, TLE1 can occupy Wnt target gene chromatin in a reciprocal manner as $\beta$ cat (Sierra et al. 2006). Like TLEs, mouse myeloid translocation gene related-1 (Mtgr1) was recently reported to bind to TCF4 and contribute to target gene silencing (Moore et al. 2008).

In addition to this corepressor mechanism, other factors contribute to silencing Wnt target genes in flies by acting in parallel to TCF (Fig. 5). CtBP is required for silencing Wnt targets, and is at WREs in a pattern similar to fly TCF (Fang et al. 2006). However, depleting TCF by RNAi had no effect on CtBP occupancy and CtBP appears to repress target gene expression in parallel to TCF/Groucho (Fang et al. 2006). The DNA-dependent ATPase ISWI, part of the ACF chromatin remodeling complex, is required for repression of Wnt targets in flies (Liu et al. 2008). Like CtBP, it is found at WREs and its localization is TCFindependent (Liu et al. 2008). Presumably, ISWI silences Wnt targets by repositioning nucleosomes at WREs. Intriguingly, although ISWI is localized to WREs, the ACF1 subunit of ACF is broadly distributed across Wnt target loci (Liu et al. 2008) (Fig. 5).

Repression of Wnt targets is relieved when sufficient $\beta$ cat enters nuclei and binds TCF. TCF's amino terminus directly binds $\beta$ cat's Arm repeats in vitro (Daniels and Weis 2002; Graham et al. 2000), but several other factors regulate this association in cells. Chibby and ICAT bind to $\beta$ cat's carboxy-terminal region, preventing TCF- $\beta$ cat interaction (Tago et al. 2000; Takemaru et al. 2003). Sox 9 can also compete with TCFs for $\beta$ cat binding (Akiyama et al. 2004), and a complex of APC and $\mathrm{CtBP}$ can bind nuclear $\beta$ cat and divert it from TCF binding (Hamada and Bienz 2004). These proteins act as TCF- $\beta$ cat "buffers," ensuring the proper threshold of $\beta$ cat is achieved before it complexes with TCFs (Fig. 5).

In addition to proteins antagonizing TCF$\beta$ cat interactions, recent reports identified factors required to stabilize the complex on target gene chromatin. The related transducin beta-like proteins TBL1 and TBLR1 are required to stabilize TCF- $\beta$ cat on target genes in mammalian and fly cell culture. They appear 
to do so through direct interactions with both TCF and $\beta$ cat (Li and Wang 2008). In mammalian cells and zebrafish embryos, nuclear Dvl and c-Jun form a complex with TCF and $\beta$ cat to promote target gene expression (Gan et al. 2008 ). These studies suggest that TCF- $\beta$ cat interaction on its own is not sufficient under physiological conditions, and needs additional proteinprotein contacts to remain on target chromatin long enough to activate gene expression.

After recruitment to TCFs at target gene loci, $\beta$ cat/Arm acts as a platform for recruiting additional coactivators (Fig. 5). Many $\beta$ catbinding factors are implicated in activating Wnt targets (reviewed in Parker et al. 2007; Stadeli et al. 2006; Willert and Jones 2006). Many, such as the histone acetyltransferases CBP and p300 (Hecht et al. 2000; Li et al. 2007b; Sun et al. 2000; Takemaru and Moon 2000) and Parafibromin/Hyrax (Mosimann et al. 2006), bind the last two Arm repeats and carboxyl terminus of $\beta$ cat and promote target gene activation. In addition, the aminoterminal portion of $\beta c a t / A r m$ recruits Legless (Lgl) in flies (Hoffmans and Basler 2004; Kramps et al. 2002) and BCL9 or BCL9-2 in vertebrates (Brembeck et al. 2004; Hoffmans and Basler 2007; Kramps et al. 2002; Sustmann et al. 2008). Lgl/BCL9 in turn recruits the PHD-finger protein Pygopus (Pygo) to the activation complex (Kramps et al. 2002; Stadeli and Basler 2005). These studies suggest that $\beta$ cat/ Arm's amino and carboxyl termini are both required to recruit distinct coactivators for activation of Wnt targets.

Intensive study of fly Pygo offers a glimpse of the complexities of transcriptional activation. In addition to Pygo's PHD domain, which binds Lgs, Pygo also contains a conserved amino-terminal homology domain (NHD). This is proposed to promote Wnt target activation by binding the mediator complex subunits Med12 and Med13 (Fig. 5) (Carrera et al. 2008), as well as the TFIID complex subunit TAF4 (Wright and Tjian 2009). In addition, Pygo's PHD domain can bind histone $\mathrm{H} 3$ methylated at lysine 4 (H3K4me). This is dependent on Lgs and is important for Pygo function in vivo (Fiedler et al. 2008).
Wnt Signaling from Development to Disease

In addition to a direct role in connecting the TCF-Arm-Lgs complex to Mediator and basal transcription machinery, Pygo and Lgs are also reported to regulate Arm nuclear translocation (Townsley et al. 2004). Furthermore, Pygo is found at WREs in the absence of signaling (de la Roche and Bienz 2007) and functions as an antirepressor, counteracting Groucho (Mieszczanek et al. 2008). Thus, Pygo acts at multiple levels to promote activation of Wnt target genes in flies.

Given the several roles it plays in Wnt signaling, it is perhaps not surprising that Pygo is required for Wnt signaling throughout fly development (Belenkaya et al. 2002; Kramps et al. 2002; Parker et al. 2002; Thompson et al. 2002). However, even though Pygo's biochemical properties are conserved in mammalian Pygo1 and Pygo2 (Fiedler et al. 2008; Kramps et al. 2002), pygo1, pygo2 or double knockouts in mice have a surprisingly mild decrease in Wnt signaling (Li et al. 2007a; Schwab et al. 2007; Song et al. 2007). Perhaps this is because mouse BCL9 contains its own transactivation domain (Sustmann et al. 2008). As the field becomes more sophisticated in understanding how Wnt target genes are activated, discrepancies between different phyla may become more commonplace.

Although extensive protein-protein interactions are clearly critical for TCF- $\beta$ cat to activate target gene expression, chromatin modifications also play a key role. Several studies in mammals showed an increase in acetylation of the histone $\mathrm{H} 3$ and $\mathrm{H} 4 \mathrm{~N}$-termini at WREs in response to pathway activation (Fig. 5) (Feng et al. 2003; Kioussi et al. 2002; Sierra et al. 2006), consistent with correlation between histone acetylation and gene activation (Grewal and Moazed 2003; Robyr et al. 2002). Increased $\mathrm{H} 3$ and $\mathrm{H} 4$ acetylation was also observed in fly cells, but here the increase was observed over the entire target gene, up to 30 $\mathrm{kB}$ away from the WREs (Parker et al. 2008). This increased histone acetylation still occurred when transcription was blocked, but was dependent on CBP. Interestingly, CBP histone acetyltransferase was restricted to the WRE (Parker et al. 2008). The purpose of widespread 
K.M. Cadigan and M. Peifer

histone acetylation is not clear, though it appears to be needed to displace ACF1, which is broadly distributed across silenced Wnt targets (Liu et al. 2008).

Finally, TCF- $\beta$ cat can also directly repress transcription (Hoverter and Waterman 2008); targets include decapentaplegic in fly imaginal discs (Theisen et al. 2007), E-cadherin in mouse keratinocytes (Jamora et al. 2003), and p16INK4a in melanomas (Delmas et al. 2007). In these cases, TCF acts through traditional sites, but TCF-Arm repression of Ugt36Bc in fly hemocytes occurs through highly divergent sites (Blauwkamp et al. 2008). Converting these divergent sites to classic ones results in Wnt signaling activating this WRE, arguing that DNA allosterically regulates the TCF-Arm complex in a profound manner. The prevalence of Wnt-mediated direct repression relative to the more commonly recognized transcriptional activation is one of many important questions requiring further study.

\section{CONCLUSIONS}

The past 5 years provided dramatic new insights into the mechanisms of Wnt signaling and its roles in development and disease. However, they also raised many new questions that promise to make the next 5 years equally exciting. For example, the roles of lipid modifications and the mechanisms of Wnt transport remain to be clarified. Signaling by $\mathrm{Fz}$ and LRP/Arrow, including possible roles for G-proteins, the function of Dvl, and the mechanisms by which the destruction complex is inactivated, are active areas of research. Interesting questions remain about the function of APC in the destruction complex, the location at which $\beta$ cat regulation occurs, and the nature of the catalytic cycle. Within the nucleus, hot topics include how TCF selects sites from the entire genome, how TCF complexes mediate both activation and repression, and which transcriptional partners are general and which are target gene or tissue specific. Despite the size of the Wnt community, we will have our hands full addressing these issues.

\section{ACKNOWLEDGMENTS}

We apologize to colleagues whose work was not cited because of space constraints. We thank David Roberts for comments and help with Figures 1 and 3. Work on Wnt signaling in the Peifer laboratory is supported by National Institutes of Health (NIH) RO1 GM67236 and in the Cadigan laboratory by NIH RO1 GM82994.

\section{REFERENCES}

Ahmed Y, Hayashi S, Levine A, Wieschaus E. 1998. Regulation of Armadillo by a Drosophila APC inhibits neuronal apoptosis during retinal development. Cell 93: $1171-1182$.

Ahmed Y, Nouri A, Wieschaus E. 2002. Drosophila Apc1 and Apc2 regulate Wingless transduction throughout development. Development 129: 1751-1762.

Akiyama H, Lyons JP, Mori-Akiyama Y, Yang X, Zhang R, Zhang Z, Deng JM, Taketo MM, Nakamura T, Behringer RR, et al. 2004. Interactions between Sox9 and $\beta$-catenin control chondrocyte differentiation. Genes Dev 18: 1072-1087.

Akong K, Grevengoed E, Price M, McCartney B, Hayden M, DeNofrio J, Peifer M. 2002a. Drosophila APC2 and APC1 play overlapping roles in wingless signaling in the embryo and imaginal discs. Dev Biol 250: 91-100.

Akong K, McCartney B, Peifer M. 2002b. Drosophila APC2 and APC1 have overlapping roles in the larval brain despite their distinct intracellular localizations. Dev Biol 250: 71-90.

Albuquerque C, Breukel C, van der Luijt R, Fidalgo P, Lage P, Slors FJ, Leitao CN, Fodde R, Smits R. 2002. The 'justright' signaling model: APC somatic mutations are selected based on a specific level of activation of the $\beta$-catenin signaling cascade. Hum Mol Genet 11: $1549-1560$.

Arce L, Yokoyama NN, Waterman ML. 2006. Diversity of LEF/TCF action in development and disease. Oncogene 25: 7492-7504.

Atcha FA, Syed A, Wu B, Hoverter NP, Yokoyama NN, Ting JH, Munguia JE, Mangalam HJ, Marsh JL, Waterman ML. 2007. A unique DNA binding domain converts T-cell factors into strong Wnt effectors. Mol Cell Biol 27: 8352-8363.

Babuke T, Tikkanen R. 2007. Dissecting the molecular function of reggie/flotillin proteins. Eur J Cell Biol 86: $525-532$.

Baig-Lewis S, Peterson-Nedry W, Wehrli M. 2007. Wingless/ Wnt signal transduction requires distinct initiation and amplification steps that both depend on Arrow/LRP. Dev Biol 306: 94-111.

Banziger C, Soldini D, Schutt C, Zipperlen P, Hausmann G, Basler K. 2006. Wntless, a conserved membrane protein dedicated to the secretion of Wnt proteins from signaling cells. Cell 125: 509-522.

Barolo S. 2006. Transgenic Wnt/TCF pathway reporters: All you need is Lef? Oncogene 25: 7505-7511. 
Bartscherer K, Boutros M. 2008. Regulation of Wnt protein secretion and its role in gradient formation. EMBO Rep 9: 977-982.

Belenkaya TY, Han C, Standley HJ, Lin X, Houston DW, Heasman J, Lin X. 2002. pygopus Encodes a nuclear protein essential for wingless/Wnt signaling. Development 129: 4089-4101.

Belenkaya TY, Wu Y, Tang X, Zhou B, Cheng L, Sharma YV, Yan D, Selva EM, Lin X. 2008. The retromer complex influences Wnt secretion by recycling wntless from endosomes to the trans-Golgi network. Dev Cell 14: 120-131.

Benchabane H, Hughes EG, Takacs CM, Baird JR, Ahmed Y. 2008. Adenomatous polyposis coli is present near the minimal level required for accurate graded responses to the Wingless morphogen. Development 135: 963-971.

Bilic J, Huang YL, Davidson G, Zimmermann T, Cruciat CM, Bienz M, Niehrs C. 2007. Wnt induces LRP6 signalosomes and promotes dishevelled-dependent LRP6 phosphorylation. Science 316: 1619-1622.

Blair SS. 2005. Cell signaling: Wingless and glypicans together again. Curr Biol 15: R92-94.

Blauwkamp TA, Chang MV, Cadigan KM. 2008. Novel TCF-binding sites specify transcriptional repression by Wnt signalling. Embo J 27: 1436-1446.

Brembeck FH, Schwarz-Romond T, Bakkers J, Wilhelm S, Hammerschmidt M, Birchmeier W. 2004. Essential role of BCL9-2 in the switch between $\beta$-catenin's adhesive and transcriptional functions. Genes Dev 18: 2225-2230.

Brocardo M, Henderson BR. 2008. APC shuttling to the membrane, nucleus and beyond. Trends Cell Biol 18: $587-596$.

Burrus LW, McMahon AP. 1995. Biochemical analysis of murine Wnt proteins reveals both shared and distinct properties. Exp Cell Res 220: 363-373.

Cabrera CV, Alonso MC, Johnston P, Phillips RG, Lawrence PA. 1987. Phenocopies induced with antisense RNA identify the wingless gene. Cell 50: 659-663.

Cadigan KM. 2002. Regulating morphogen gradients in the Drosophila wing. Semin Cell Dev Biol 13: 83-90.

Cadigan KM, Liu YI. 2006. Wnt signaling: Complexity at the surface. J Cell Sci 119: 395-402.

Capdevila J, Izpisua Belmonte JC. 2001. Patterning mechanisms controlling vertebrate limb development. Annu Rev Cell Dev Biol 17: 87-132.

Carrera I, Janody F, Leeds N, Duveau F, Treisman JE. 2008. Pygopus activates Wingless target gene transcription through the mediator complex subunits Med12 and Med13. Proc Natl Acad Sci 105: 6644-6649.

Cavallo RA, Cox RT, Moline MM, Roose J, Polevoy GA, Clevers H, Peifer M, Bejsovec A. 1998. Drosophila Tcf and Groucho interact to repress Wingless signalling activity. Nature 395: 604-608.

Cayuso J, Marti E. 2005. Morphogens in motion: Growth control of the neural tube. J Neurobiol 64: 376-387.

Chang JL, Chang MV, Barolo S, Cadigan KM. 2008a. Regulation of the feedback antagonist naked cuticle by Wingless signaling. Dev Biol 321: 446-454.

Chang MV, Chang JL, Gangopadhyay A, Shearer A, Cadigan KM. 2008b. Activation of wingless targets requires bipartite recognition of DNA by TCF. Curr Biol 18: 1877-1881.
Wnt Signaling from Development to Disease

Chen HJ, Lin CM, Lin CS, Perez-Olle R, Leung CL, Liem RK. 2006. The role of microtubule actin cross-linking factor 1 (MACF1) in the Wnt signaling pathway. Genes Dev 20: $1933-1945$.

Chia IV, Costantini F. 2005. Mouse axin and axin2/conductin proteins are functionally equivalent in vivo. $\mathrm{Mol} \mathrm{Cell}$ Biol 25: 4371-4376.

Ching W, Nusse R. 2006. A dedicated Wnt secretion factor. Cell 125: 432-433.

Ching W, Hang HC, Nusse R. 2008. Lipid-independent secretion of a Drosophila Wnt protein. J Biol Chem 283: $17092-17098$.

Choi HJ, Huber AH, Weis WI. 2006. Thermodynamics of $\beta$-catenin-ligand interactions: The roles of the $\mathrm{N}$-and C-terminal tails in modulating binding affinity. J Biol Chem 281: 1027-1038.

Clevers H. 2006. Wnt/ $\beta$-catenin signaling in development and disease. Cell 127: 469-480.

Cong F, Schweizer L, Varmus H. 2004. Wnt signals across the plasma membrane to activate the $\beta$-catenin pathway by forming oligomers containing its receptors, Frizzled and LRP. Development 131: 5103-5115.

Cselenyi CS, Jernigan KK, Tahinci E, Thorne CA, Lee LA, Lee E. 2008. LRP6 transduces a canonical Wnt signal independently of Axin degradation by inhibiting GSK3's phosphorylation of $\beta$-catenin. Proc Natl Acad Sci 105: 8032-8037.

Daniels DL, Weis WI. 2002. ICAT inhibits $\beta$-catenin binding to Tcf/Lef-family transcription factors and the general coactivator p300 using independent structural modules. Mol Cell 10: 573-584.

Daniels DL, Weis WI. 2005. $\beta$-Catenin directly displaces Groucho/TLE repressors from Tcf/Lef in Wnt-mediated transcription activation. Nat Struct Mol Biol 12: 364-371.

Davidson G, Wu W, Shen J, Bilic J, Fenger U, Stannek P, Glinka A, Niehrs C. 2005. Casein kinase $1 \gamma$ couples Wnt receptor activation to cytoplasmic signal transduction. Nature 438: 867-872.

de la Roche M, Bienz M. 2007. Wingless-independent association of Pygopus with dTCF target genes. Curr Biol 17: 556-561.

Delmas V, Beermann F, Martinozzi S, Carreira S, Ackermann J, Kumasaka M, Denat L, Goodall J, Luciani F, Viros A, et al. 2007. $\beta$-Catenin induces immortalization of melanocytes by suppressing p16INK4a expression and cooperates with N-Ras in melanoma development. Genes Dev 21: 2923-2935.

DiNardo S, Heemskerk J, Dougan S, O'Farrell PH. 1994. The making of a maggot: Patterning the Drosophila embryonic epidermis. Curr Opin Genet Dev 4: 529-534.

Doughman RL, Firestone AJ, Anderson RA. 2003. Phosphatidylinositol phosphate kinases put PI4,5P(2) in its place. J Membr Biol 194: 77-89.

Eaton S. 2008. Retromer retrieves wntless. Dev Cell 14: 4-6.

Essers MA, de Vries-Smits LM, Barker N, Polderman PE, Burgering BM, Korswagen HC. 2005. Functional interaction between $\beta$-catenin and FOXO in oxidative stress signaling. Science 308: 1181-1184.

Fang M, Li J, Blauwkamp T, Bhambhani C, Campbell N, Cadigan KM. 2006. C-terminal-binding protein directly 
K.M. Cadigan and M. Peifer

activates and represses Wnt transcriptional targets in Drosophila. Embo J 25: 2735-2745.

Fanto M, McNeill H. 2004. Planar polarity from flies to vertebrates. J Cell Sci 117: 527-533.

Faux MC, Coates JL, Catimel B, Cody S, Clayton AH, Layton MJ, Burgess AW. 2008. Recruitment of adenomatous polyposis coli and $\beta$-catenin to axin-puncta. Oncogene 27: $5808-5820$.

Feng Y, Lee N, Fearon ER. 2003. TIP49 regulates $\beta$-cateninmediated neoplastic transformation and T-cell factor target gene induction via effects on chromatin remodeling. Cancer Res 63: 8726-8734.

Fiedler M, Sanchez-Barrena MJ, Nekrasov M, Mieszczanek J, Rybin V, Muller J, Evans P, Bienz M. 2008. Decoding of methylated histone $\mathrm{H} 3$ tail by the Pygo-BCL9 Wnt signaling complex. Mol Cell 30: 507-518.

Franch-Marro X, Marchand O, Piddini E, Ricardo S, Alexandre C, Vincent JP. 2005. Glypicans shunt the Wingless signal between local signalling and further transport. Development 132: 659-666.

Franch-Marro X, Wendler F, Griffith J, Maurice MM, Vincent JP. 2008a. In vivo role of lipid adducts on Wingless. J Cell Sci 121: 1587-1592.

Franch-Marro X, Wendler F, Guidato S, Griffith J, BaenaLopez A, Itasaki N, Maurice MM, Vincent JP. 2008b. Wingless secretion requires endosome-to-Golgi retrieval of Wntless/Evi/Sprinter by the retromer complex. Nat Cell Biol 10: 170-177.

Gallet A, Staccini-Lavenant L, Therond PP. 2008. Cellular trafficking of the glypican Dally-like is required for fullstrength Hedgehog signaling and wingless transcytosis. Dev Cell 14: 712-725.

Galli LM, Barnes TL, Secrest SS, Kadowaki T, Burrus LW. 2007. Porcupine-mediated lipid-modification regulates the activity and distribution of Wnt proteins in the chick neural tube. Development 134: 3339-3348.

Gan XQ, Wang JY, Xi Y, Wu ZL, Li YP, Li L. 2008. Nuclear Dvl, c-Jun, $\beta$-catenin, and TCF form a complex leading to stabilization of $\beta$-catenin-TCF interaction. J Cell Biol 180: $1087-1100$.

Giraldez AJ, Copley RR, Cohen SM. 2002. HSPG modification by the secreted enzyme Notum shapes the Wingless morphogen gradient. Dev Cell 2: 667-676.

Gordon MD, Nusse R. 2006. Wnt signaling: Multiple pathways, multiple receptors, and multiple transcription factors. J Biol Chem 281: 22429-22433.

Graham TA, Weaver C, Mao F, Kimelman D, Xu W. 2000. Crystal structure of a $\beta$-catenin/Tcf complex. Cell 103: 885-896.

Gregory SL, Ebrahimi S, Milverton J, Jones WM, Bejsovec A, Saint R. 2008. Cell division requires a direct link between microtubule-bound RacGAP and Anillin in the contractile ring. Curr Biol 18: 25-29.

Grewal SI, Moazed D. 2003. Heterochromatin and epigenetic control of gene expression. Science 301: 798-802.

Grohmann A, Tanneberger K, Alzner A, Schneikert J, Behrens J. 2007. AMER1 regulates the distribution of the tumor suppressor APC between microtubules and the plasma membrane. J Cell Sci 120: 3738-3747.

Ha NC, Tonozuka T, Stamos JL, Choi HJ, Weis WI. 2004. Mechanism of phosphorylation-dependent binding of
APC to $\beta$-catenin and its role in $\beta$-catenin degradation. Mol Cell 15: 511-521.

Hallikas O, Palin K, Sinjushina N, Rautiainen R, Partanen J, Ukkonen E, Taipale J. 2006. Genome-wide prediction of mammalian enhancers based on analysis of transcription-factor binding affinity. Cell 124: 47-59.

Hamada F, Bienz M. 2002. A Drosophila APC tumour suppressor homologue functions in cellular adhesion. Nat Cell Biol 4: 208-213.

Hamada F, Bienz M. 2004. The APC tumor suppressor binds to C-terminal binding protein to divert nuclear $\beta$-catenin from TCF. Dev Cell 7: 677-685.

Hamada F, Tomoyasu Y, Takatsu Y, Nakamura M, Nagai S, Suzuki A, Fujita F, Shibuya H, Toyoshima K, Ueno N, et al. 1999. Negative regulation of Wingless signaling by D-axin, a Drosophila homolog of axin. Science 283: 1739-1742.

Han C, Yan D, Belenkaya TY, Lin X. 2005. Drosophila glypicans Dally and Dally-like shape the extracellular Wingless morphogen gradient in the wing disc. Development 132: 667-679.

Hardin J, King RS. 2008. The long and the short of Wnt signaling in C. elegans. Curr Opin Genet Dev 18: 362-367.

Hayashi S, Rubinfeld B, Souza B, Polakis P, Wieschaus E, Levine A. 1997. A Drosophila homolog of the tumor suppressor gene adenomatous polyposis coli downregulates $B$-catenin but its zygotic expression is not essential for the regulation of Armadillo. Proc Natl Acad Sci 94: 242-247.

He X, Semenov M, Tamai K, Zeng X. 2004. LDL receptorrelated proteins 5 and 6 in Wnt/ $\beta$-catenin signaling: Arrows point the way. Development 131: 1663-1677.

Hecht A, Vleminckx K, Stemmler MP, van Roy F, Kemler R. 2000. The p300/CBP acetyltransferases function as transcriptional coactivators of $\beta$-catenin in vertebrates. Embo J 19: 1839-1850.

Hendriksen J, Jansen M, Brown CM, van der Velde H, van Ham M, Galjart N, Offerhaus GJ, Fagotto F, Fornerod M. 2008. Plasma membrane recruitment of dephosphorylated $\beta$-catenin upon activation of the Wnt pathway. J Cell Sci 121: 1793-1802.

Heuberger J, Birchmeier W. 2009. Interplay of cadherinmediated cell adhesion and canonical Wnt signaling. Cold Spring Harb Perspect Biol 2: a002915.

Hoffmans R, Basler K. 2004. Identification and in vivo role of the Armadillo-Legless interaction. Development 131: $4393-4400$

Hoffmans R, Basler K. 2007. BCL9-2 binds Arm/ $\beta$-catenin in a Tyr142-independent manner and requires Pygopus for its function in $\mathrm{Wg} / \mathrm{Wnt}$ signaling. Mech Dev 124: $59-67$.

Holmen SL, Robertson SA, Zylstra CR, Williams BO. 2005. Wnt-independent activation of $\beta$-catenin mediated by a Dkk1-Fz5 fusion protein. Biochem Biophys Res Commun 328: 533-539.

Hoverter NP, Waterman ML. 2008. AWnt-fall for gene regulation: Repression. Sci Signal 1: pe43.

Jamora C, DasGupta R, Kocieniewski P, Fuchs E. 2003. Links between signal transduction, transcription and adhesion in epithelial bud development. Nature 422: 317-322. 
Jones WM, Bejsovec A. 2005. RacGap50C negatively regulates wingless pathway activity during Drosophila embryonic development. Genetics 169: 2075-2086.

Kadowaki T, Wilder E, Klingensmith J, Zachary K, Perrimon N. 1996. The segment polarity gene porcupine encodes a putative multitransmembrane protein involved in Wingless processing. Genes Dev 10: 3116-3128.

Katanaev VL, Ponzielli R, Semeriva M, Tomlinson A. 2005. Trimeric $G$ protein-dependent frizzled signaling in Drosophila. Cell 120: 111-122.

Katanaev VL, Solis GP, Hausmann G, Buestorf S, Katanayeva N, Schrock Y, Stuermer CA, Basler K. 2008. Reggie-1/ flotillin-2 promotes secretion of the long-range signalling forms of Wingless and Hedgehog in Drosophila. Embo J 27: $509-521$.

Kimelman D, Xu W. 2006. $\beta$-Catenin destruction complex: Insights and questions from a structural perspective. Oncogene 25: 7482-7491.

Kioussi C, Briata P, Baek SH, Rose DW, Hamblet NS, Herman T, Ohgi KA, Lin C, Gleiberman A, Wang J, et al. 2002. Identification of a Wnt/Dvl/ $\beta$-Catenin $->$ Pitx2 pathway mediating cell-type-specific proliferation during development. Cell 111: 673-685.

Kirkpatrick CA, Dimitroff BD, Rawson JM, Selleck SB. 2004. Spatial regulation of Wingless morphogen distribution and signaling by Dally-like protein. Dev Cell 7: 513-523.

Koesters R, Ridder R, Kopp-Schneider A, Betts D, Adams V, Niggli F, Briner J, von Knebel Doeberitz M. 1999. Mutational activation of the $\beta$-catenin proto-oncogene is a common event in the development of Wilms' tumors. Cancer Res 59: 3880-3882.

Kofron M, Birsoy B, Houston D, Tao Q, Wylie C, Heasman J. 2007. Wnt11/ $\beta$-catenin signaling in both oocytes and early embryos acts through LRP6-mediated regulation of axin. Development 134: 503-513.

Kohler EM, Chandra SH, Behrens J, Schneikert J. 2009. $\beta$-Catenin degradation mediated by the CID domain of APC provides a model for the selection of APC mutations in colorectal, desmoid and duodenal tumours. Hum Mol Genet 18: 213-226.

Kohn AD, Moon RT. 2005. Wnt and calcium signaling: $\beta$-catenin-independent pathways. Cell Calcium 38: $439-446$.

Komekado H, Yamamoto H, Chiba T, Kikuchi A. 2007. Glycosylation and palmitoylation of Wnt-3a are coupled to produce an active form of Wnt-3a. Genes Cells 12: 521-534.

Korswagen HC, Coudreuse DY, Betist MC, van de Water S, Zivkovic D, Clevers HC. 2002. The Axin-like protein PRY-1 is a negative regulator of a canonical Wnt pathway in C. elegans. Genes Dev 16: 1291-1302.

Kramps T, Peter O, Brunner E, Nellen D, Froesch B, Chatterjee S, Murone M, Zullig S, Basler K. 2002. $\mathrm{Wnt} /$ wingless signaling requires BCL9/legless-mediated recruitment of pygopus to the nuclear $\beta$-catenin-TCF complex. Cell 109: 47-60.

Kreuger J, Perez L, Giraldez AJ, Cohen SM. 2004. Opposing activities of Dally-like glypican at high and low levels of Wingless morphogen activity. Dev Cell 7: 503-512.
Wnt Signaling from Development to Disease

Krieghoff E, Behrens J, Mayr B. 2006. Nucleo-cytoplasmic distribution of $\beta$-catenin is regulated by retention. $J$ Cell Sci 119: 1453-1463.

Kurayoshi M, Yamamoto H, Izumi S, Kikuchi A. 2007. Post-translational palmitoylation and glycosylation of Wnt-5a are necessary for its signalling. Biochem J 402: 515-523.

Lammi L, Arte S, Somer M, Jarvinen H, Lahermo P, Thesleff I, Pirinen S, Nieminen P. 2004. Mutations in AXIN2 cause familial tooth agenesis and predispose to colorectal cancer. Am J Hum Genet 74: 1043-1050.

Langhorst MF, Reuter A, Stuermer CA. 2005. Scaffolding microdomains and beyond: The function of reggie/flotillin proteins. Cell Mol Life Sci 62: 2228-2240.

Langhorst MF, Reuter A, Jaeger FA, Wippich FM, Luxenhofer G, Plattner H, Stuermer CA. 2008. Trafficking of the microdomain scaffolding protein reggie-1/flotillin-2. Eur J Cell Biol 87: 211-226.

Laudet V, Stehelin D, Clevers H. 1993. Ancestry and diversity of the HMG box superfamily. Nucleic Acids Res 21: 2493-2501.

Le Lay S, Kurzchalia TV. 2005. Getting rid of caveolins: Phenotypes of caveolin-deficient animals. Biochim Biophys Acta 1746: 322-333.

Lee HH, Frasch M. 2000. Wingless effects mesoderm patterning and ectoderm segmentation events via induction of its downstream target sloppy paired. Development 127: $5497-5508$.

Li J, Wang CY. 2008. TBL1-TBLR1 and $\beta$-catenin recruit each other to Wnt target-gene promoter for transcription activation and oncogenesis. Nat Cell Biol 10: 160-169.

Li B, Rheaume C, Teng A, Bilanchone V, Munguia JE, Hu M, Jessen S, Piccolo S, Waterman ML, Dai X. 2007a. Developmental phenotypes and reduced Wnt signaling in mice deficient for pygopus 2. Genesis 45: 318-325.

Li J, Sutter C, Parker DS, Blauwkamp T, Fang M, Cadigan KM. 2007b. CBP/p300 are bimodal regulators of Wnt signaling. Embo J 26: 2284-2294.

Liu X, Rubin JS, Kimmel AR. 2005. Rapid, Wnt-induced changes in GSK3 $\beta$ associations that regulate $\beta$-catenin stabilization are mediated by $\mathrm{G} \alpha$ proteins. Curr Biol 15: 1989-1997.

Liu J, Xing Y, Hinds TR, Zheng J, Xu W. 2006. The third 20 amino acid repeat is the tightest binding site of APC for $\beta$-catenin. J Mol Biol 360: 133-144.

Liu YI, Chang MV, Li HE, Barolo S, Chang JL, Blauwkamp TA, Cadigan KM. 2008. The chromatin remodelers ISWI and ACF1 directly repress Wingless transcriptional targets. Dev Biol 323: 41-52.

MacDonald BT, Yokota C, Tamai K, Zeng X, He X. 2008. Wnt signal amplification via activity, cooperativity, and regulation of multiple intracellular PPPSP motifs in the Wnt co-receptor LRP6. J Biol Chem 283: 16115-16123.

Major MB, Camp ND, Berndt JD, Yi X, Goldenberg SJ, Hubbert C, Biechele TL, Gingras AC, Zheng N, Maccoss MJ, et al. 2007. Wilms tumor suppressor WTX negatively regulates $\mathrm{WNT} / \beta$-catenin signaling. Science 316: 1043-1046.

Mao J, Wang J, Liu B, Pan W, Farr GH3rd, Flynn C, Yuan H, Takada S, Kimelman D, Li L, Wu D. 2001. Low-density lipoprotein receptor-related protein-5 binds to Axin 
K.M. Cadigan and M. Peifer

and regulates the canonical Wnt signaling pathway. $\mathrm{Mol}$ Cell 7: 801-809.

Marois E, Mahmoud A, Eaton S. 2006. The endocytic pathway and formation of the Wingless morphogen gradient. Development 133: 307-317.

Mason JO, Kitajewski J, Varmus HE. 1992. Mutational analysis of mouse Wnt-1 identifies two temperaturesensitive alleles and attributes of Wnt-1 protein essentia for transformation of a mammary cell line. Mol Biol Cell 3: 521-533.

McCartney BM, Dierick HA, Kirkpatrick C, Moline MM Baas A, Peifer M, Bejsovec A. 1999. Drosophila APC2 is a cytoskeletally-associated protein that regulates Wingless signaling in the embryonic epidermis. J Cell Biol 146: 1303-1318.

McCartney BM, Price MH, Webb RL, Hayden MA, Holot LM, Zhou M, Bejsovec A, Peifer M. 2006. Testing hypotheses for the functions of APC family proteins using nul and truncation alleles in Drosophila. Development 133: 2407-2418.

McCrea P, Turck C, Gumbiner B. 1991. A homolog of Drosophila armadillo (plakoglobin) associated with the cytoplasmic tail of E-cadherin. Science 254: 1359-1361.

Mieszczanek J, de la Roche M, Bienz M. 2008. A role of Pygopus as an anti-repressor in facilitating Wntdependent transcription. Proc Natl Acad Sci 105: 19324-19329.

Mizumoto K, Sawa H. 2007. Cortical $\beta$-catenin and APC regulate asymmetric nuclear $\beta$-catenin localization during asymmetric cell division in C. elegans. Dev Cell 12: $287-299$.

Moore AC, Amann JM, Williams CS, Tahinci E, Farmer TE, Martinez JA, Yang G, Luce KS, Lee E, Hiebert SW. 2008 Myeloid translocation gene family members associate with T-cell factors (TCFs) and influence TCF-dependent transcription. Mol Cell Biol 28: 977-987.

Mosimann C, Hausmann G, Basler K. 2006. Parafibromin/ Hyrax activates Wnt/Wg target gene transcription by direct association with $\beta$-catenin/Armadillo. Cell 125: 327-341.

Munemitsu S, Souza B, Albert I, Rubinfeld B, Polakis P. 1995. Regulation of intracellular $ß$-catenin levels by the adenomatous polyposis coli (APC) tumor suppressor protein. Proc Natl Acad Sci 92: 3046-3050.

Näthke I. 2006. Cytoskeleton out of the cupboard: Colon cancer and cytoskeletal changes induced by loss of APC. Nat Rev Cancer 6: 967-974.

Näthke IS, Adams CL, Polakis P, Sellin JH, Nelson WJ. 1996. The Adenomatous Polyposis Coli (APC) tumor suppressor protein localizes to plasma membrane sites involved in active cell migration. J Cell Biol 134: 165-180.

Noordermeer J, Klingensmith J, Perrimon N, Nusse R. 1994. dishevelled and armadillo act in the wingless signalling pathway in Drosophila. Nature 367: 80-83.

Nusse R. 2003. Wnts and Hedgehogs: Lipid-modified proteins and similarities in signaling mechanisms at the cell surface. Development 130: 5297-5305.

Ohshima R, Ohta T, Wu W, Koike A, Iwatani T, Henderson M, Watts CK, Otsubo T. 2007. Putative tumor suppressor EDD interacts with and up-regulates APC. Genes Cells 12: $1339-1345$.
Oosterveen T, Coudreuse DY, Yang PT, Fraser E, Bergsma J, Dale TC, Korswagen HC. 2007. Two functionally distinct Axin-like proteins regulate canonical Wnt signaling in C. elegans. Dev Biol 308: 438-448.

Pan CL, Baum PD, Gu M, Jorgensen EM, Clark SG, Garriga G. 2008a. C. elegans AP-2 and retromer control Wnt signaling by regulating mig-14/Wntless. Dev Cell 14: $132-139$.

Pan W, Choi SC, Wang H, Qin Y, Volpicelli-Daley L, Swan L, Lucast L, Khoo C, Zhang X, Li L, et al. 2008b. Wnt3a-mediated formation of phosphatidylinositol 4,5-bisphosphate regulates LRP6 phosphorylation. Science 321: 1350-1353.

Panakova D, Sprong H, Marois E, Thiele C, Eaton S. 2005. Lipoprotein particles are required for Hedgehog and Wingless signalling. Nature 435: 58-65.

Parker DS, Jemison J, Cadigan KM. 2002. Pygopus, a nuclear PHD-finger protein required for Wingless signaling in Drosophila. Development 129: 2565-2576.

Parker DS, Blauwkamp T, Cadigan KM. 2007. Wnt/ $\beta$-catenin-mediated transcriptional regulation. In Wnt Signaling in Embryonic Development, (ed. S. Sokol) Advances in Developmental Biology, Wassarman PM (ed), Vol. 17, pp. 1-61. San Diego: Elsevier.

Parker DS, Ni YY, Chang JL, Li J, Cadigan KM. 2008. Wingless signaling induces widespread chromatin remodeling of target loci. Mol Cell Biol 28: 1815-1828.

Peifer M, Wieschaus E. 1990. The segment polarity gene armadillo encodes a functionally modular protein that is the Drosophila homolog of human plakoglobin. Cell 63: 1167-1178.

Peifer M, Berg S, Reynolds AB. 1994. A repeating amino acid motif shared by proteins with diverse cellular roles. Cell 76: 789-791.

Peifer M, McCrea PD, Green KJ, Wieschaus E, Gumbiner BM. 1992. The vertebrate adhesive junction proteins $\beta$-catenin and plakoglobin and the Drosophila segment polarity gene armadillo form a multigene family with similar properties. J Cell Biol 118: 681-691.

Peterson-Nedry W, Erdeniz N, Kremer S, Yu J, Baig-Lewis S, Wehrli M. 2008. Unexpectedly robust assembly of the Axin destruction complex regulates Wnt/Wg signaling in Drosophila as revealed by analysis in vivo. Dev Biol 320: $226-241$.

Pfeiffer S, Ricardo S, Manneville JB, Alexandre C, Vincent JP. 2002. Producing cells retain and recycle Wingless in Drosophila embryos. Curr Biol 12: 957-962.

Piao S, Lee SH, Kim H, Yum S, Stamos JL, Xu Y, Lee SJ, Lee J, Oh S, Han JK, et al. 2008. Direct inhibition of GSK3 $\beta$ by the phosphorylated cytoplasmic domain of LRP6 in Wnt/ $\beta$-catenin signaling. PLoS ONE 3: e4046.

Piddini E, Marshall F, Dubois L, Hirst E, Vincent JP. 2005. Arrow (LRP6) and Frizzled2 cooperate to degrade Wingless in Drosophila imaginal discs. Development 132: $5479-5489$.

Polakis P. 1995. Mutations in the APC gene and their implications for protein structure and function. Curr Opin Genet Dev 5: 66-71.

Polakis P. 2007. The many ways of Wnt in cancer. Curr Opin Genet Dev 17: 45-51. 
Port F, Kuster M, Herr P, Furger E, Banziger C, Hausmann G, Basler K. 2008. Wingless secretion promotes and requires retromer-dependent cycling of Wntless. Nat Cell Biol 10: 178-185.

Riese J, Yu X, Munnerlyn A, Eresh S, Hsu SC, Grosschedl R, Bienz M. 1997. LEF-1, a nuclear factor coordinating signaling inputs from wingless and decapentaplegic. Cell 88: 777-787.

Rijsewijk F, Schuermann M, Wagenaar E, Parren P, Weigel D, Nusse R. 1987. The Drosophila homologue of the mouse mammary oncogene int-1 is identical to the segment polarity gene wingless. Cell 50: 647-657.

Rivera MN, Kim WJ, Wells J, Driscoll DR, Brannigan BW, Han M, Kim JC, Feinberg AP, Gerald WL, Vargas SO, et al. 2007. An X chromosome gene, WTX, is commonly inactivated in Wilms tumor. Science 315: 642-645.

Roberts DM, Slep KC, Peifer M. 2007. It takes more than two to tango: Dishevelled polymerization and Wnt signaling. Nat Struct Mol Biol 14: 463-465.

Robyr D, Suka Y, Xenarios I, Kurdistani SK, Wang A, Suka N, Grunstein M. 2002. Microarray deacetylation maps determine genome-wide functions for yeast histone deacetylases. Cell 109: 437-446.

Roose J, Molenaar M, Peterson J, Hurenkamp J, Brantjes H, Moerer P, van de Wetering M, Destree O, Clevers H. 1998. The Xenopus Wnt effector XTcf-3 interacts with Groucho-related transcriptional repressors. Nature 395: 608-612.

Rousset R, Mack JA, Wharton KAJr, Axelrod JD, Cadigan KM, Fish MP, Nusse R, Scott MP. 2001. naked cuticle targets dishevelled to antagonize Wnt signal transduction. Genes Dev 15: 658-671.

Rubinfeld B, Souza B, Albert I, Muller O, Chamberlain SH, Masiarz FR, Munemitsu S, Polakis P. 1993. The APC gene product associates with ß-catenin. Science 262: 1731-1734.

Rubinfeld B, Albert I, Porfiri E, Munemitsu S, Polakis P. 1997. Loss of B-Catenin Regulation by the APC Tumor Suppressor Protein Correlates with Loss of Structure Due to Common Somatic Mutations of the Gene. Cancer Res 57: 4624-4630.

Schneider SQ, Bowerman B. 2007. $\beta$-Catenin asymmetries after all animal/vegetal- oriented cell divisions in Platynereis dumerilii embryos mediate binary cell-fate specification. Dev Cell 13: 73-86.

Schwab KR, Patterson LT, Hartman HA, Song N, Lang RA, Lin X, Potter SS. 2007. Pygo1 and Pygo2 roles in Wnt signaling in mammalian kidney development. $B M C$ Biol 5: 15.

Schwarz-Romond T, Fiedler M, Shibata N, Butler PJ, Kikuchi A, Higuchi Y, Bienz M. 2007a. The DIX domain of Dishevelled confers Wnt signaling by dynamic polymerization. Nat Struct Mol Biol 14: 484-492.

Schwarz-Romond T, Metcalfe C, Bienz M. 2007b. Dynamic recruitment of axin by Dishevelled protein assemblies. J Cell Sci 120: 2402-2412.

Seaman MN. 2005. Recycle your receptors with retromer. Trends Cell Biol 15: 68-75.

Semenov MV, Habas R, Macdonald BT, He X. 2007. SnapShot: Noncanonical Wnt signaling pathways. Cell 131: 1378.
Wnt Signaling from Development to Disease

Sierra J, Yoshida T, Joazeiro CA, Jones KA. 2006. The APC tumor suppressor counteracts $\beta$-catenin activation and H3K4 methylation at Wnt target genes. Genes Dev 20: 586-600.

Sinner D, Rankin S, Lee M, Zorn AM. 2004. Sox17 and $\beta$-catenin cooperate to regulate the transcription of endodermal genes. Development 131: 3069-3080.

Smits R, Kielman MF, Breukel C, Zurcher C, Neufeld K, Jagmohan-Changur S, Hofland N, van Dijk J, White R, Edelmann W, et al. 1999. Apc1638T: A mouse model delineating critical domains of the adenomatous polyposis coli protein involved in tumorigenesis and development. Genes Dev 13: 1309-1321.

Smolich BD, McMahon JA, McMahon AP, Papkoff J. 1993. Wnt family proteins are secreted and associated with the cell surface. Mol Biol Cell 4: 1267-1275.

Song N, Schwab KR, Patterson LT, Yamaguchi T, Lin X, Potter SS, Lang RA. 2007. pygopus 2 has a crucial, Wnt pathway-independent function in lens induction. Development 134: 1873-1885.

Sotgia F, Williams TM, Cohen AW, Minetti C, Pestell RG, Lisanti MP. 2005. Caveolin-1-deficient mice have an increased mammary stem cell population with upregulation of $\mathrm{Wnt} / \beta$-catenin signaling. Cell Cycle 4: 1808-1816.

Stadeli R, Basler K. 2005. Dissecting nuclear Wingless signalling: Recruitment of the transcriptional co-activator Pygopus by a chain of adaptor proteins. Mech Dev 122: $1171-1182$.

Stadeli R, Hoffmans R, Basler K. 2006. Transcription under the control of nuclear Arm $/ \beta$-catenin. Curr Biol 16: R378-385.

Strigini M, Cohen SM. 1999. Formation of morphogen gradients in the Drosophila wing. Semin Cell Dev Biol 10: $335-344$.

Su L-K, Vogelstein B, Kinzler KW. 1993. The APC tumor suppressor protein associates with catenins. Science 262: 1734-1737.

Su Y, Fu C, Ishikawa S, Stella A, Kojima M, Shitoh K, Schreiber EM, Day BW, Liu B. 2008. APC is essential for targeting phosphorylated $\beta$-catenin to the SCF $\beta$-TrCP ubiquitin ligase. Mol Cell 32: 652-661.

Sun Y, Kolligs FT, Hottiger MO, Mosavin R, Fearon ER, Nabel GJ. 2000. Regulation of $\beta$-catenin transformation by the p300 transcriptional coactivator. Proc Natl Acad Sci 97: 12613-12618.

Sustmann C, Flach H, Ebert H, Eastman Q, Grosschedl R. 2008. Cell-type-specific function of BCL9 involves a transcriptional activation domain that synergizes with $\beta$-catenin. Mol Cell Biol 28: 3526-3537.

Tago K, Nakamura T, Nishita M, Hyodo J, Nagai S, Murata Y, Adachi S, Ohwada S, Morishita Y, Shibuya H, Akiyama T. 2000. Inhibition of Wnt signaling by ICAT, a novel $\beta$-catenin-interacting protein. Genes Dev 14: 1741-1749.

Takacs CM, Baird JR, Hughes EG, Kent SS, Benchabane H, Paik R, Ahmed Y. 2008. Dual positive and negative regulation of wingless signaling by adenomatous polyposis coli. Science 319: 333-336.

Takada R, Satomi Y, Kurata T, Ueno N, Norioka S, Kondoh H, Takao T, Takada S. 2006. Monounsaturated fatty acid 
K.M. Cadigan and M. Peifer

modification of Wnt protein: Its role in Wnt secretion. Dev Cell 11: 791-801.

Takemaru KI, Moon RT. 2000. The transcriptional coactivator CBP interacts with $\beta$-catenin to activate gene expression. J Cell Biol 149: 249-254.

Takemaru K, Yamaguchi S, Lee YS, Zhang Y, Carthew RW, Moon RT. 2003. Chibby, a nuclear $\beta$-catenin-associated antagonist of the Wnt/Wingless pathway. Nature 422: 905-909.

Takeshita H, Sawa H. 2005. Asymmetric cortical and nuclear localizations of WRM- $1 / \beta$-catenin during asymmetric cell division in C. elegans. Genes Dev 19: 1743-1748.

Tamai K, Semenov M, Kato Y, Spokony R, Liu C, Katsuyama Y, Hess F, Saint-Jeannet JP, He X. 2000. LDL-receptorrelated proteins in Wnt signal transduction. Nature 407: 530-535.

Tamai K, Zeng X, Liu C, Zhang X, Harada Y, Chang Z, He X. 2004. A mechanism for Wnt coreceptor activation. Mol Cell 13: 149-156.

Tanaka K, Kitagawa Y, Kadowaki T. 2002. Drosophila segment polarity gene product porcupine stimulates the posttranslational $\mathrm{N}$-glycosylation of wingless in the endoplasmic reticulum. J Biol Chem 277: 12816-12823.

Theisen H, Syed A, Nguyen BT, Lukacsovich T, Purcell J Srivastava GP, Iron D, Gaudenz K, Nie Q, Wan FY, et al. 2007. Wingless directly represses DPP morphogen expression via an armadillo/TCF/Brinker complex. PLoS ONE 2: e142.

Thompson B, Townsley F, Rosin-Arbesfeld R, Musisi H, Bienz M. 2002. A new nuclear component of the Wnt signalling pathway. Nat Cell Biol 4: 367-373.

Tolwinski NS, Wieschaus E. 2001. Armadillo nuclear import is regulated by cytoplasmic anchor Axin and nuclear anchor dTCF/Pan. Development 128: 2107-2117.

Tolwinski NS, Wehrli M, Rives A, Erdeniz N, DiNardo S, Wieschaus E. 2003. Wg/Wnt signal can be transmitted through arrow/LRP5,6 and Axin independently of Zw3/Gsk3 $\beta$ activity. Dev Cell 4: 407-418.

Townsley FM, Cliffe A, Bienz M. 2004. Pygopus and Legless target Armadillo/ $\beta$-catenin to the nucleus to enable its transcriptional co-activator function. Nat Cell Biol 6: 626-633.

van Amerongen R, Mikels A, Nusse R. 2008. Alternative wnt signaling is initiated by distinct receptors. Sci Signal 1: pre9.

van den Heuvel M, Harryman-Samos C, Klingensmith J, Perrimon N, Nusse R. 1993. Mutations in the segment polarity genes wingless and porcupine impair secretion of the wingless protein. Embo J 12: 5293-5302.

Van Raay TJ, Coffey RJ, Solnica-Krezel L. 2007. Zebrafish Naked 1 and Naked2 antagonize both canonical and noncanonical Wnt signaling. Dev Biol 309: 151-168.

Veeman MT, Axelrod JD, Moon RT. 2003. A second canon. Functions and mechanisms of $\beta$-catenin-independent Wnt signaling. Dev Cell 5: 367-377.

Wallingford JB, Habas R. 2005. The developmental biology of Dishevelled: An enigmatic protein governing cell fate and cell polarity. Development 132: 4421-4436.

Wharton KAJr. 2003. Runnin' with the Dvl: Proteins that associate with Dsh/Dvl and their significance to Wnt signal transduction. Dev Biol 253: 1-17.
Wharton KAJr, Zimmermann G, Rousset R, Scott MP. 2001 Vertebrate proteins related to Drosophila naked cuticle bind dishevelled and antagonize wnt signaling. Dev Biol 234: 93-106.

Willert K, Jones KA. 2006. Wnt signaling: Is the party in the nucleus? Genes Dev 20: 1394-1404.

Willert K, Logan CY, Arora A, Fish M, Nusse R. 1999. A Drosophila Axin homolog, Daxin, inhibits Wnt signaling. Development 126: 4165-4173.

Willert K, Brown JD, Danenberg E, Duncan AW, Weissman IL, Reya T, Yates JR3rd, Nusse R. 2003. Wnt proteins are lipid-modified and can act as stem cell growth factors. Nature 423: 448-452.

Wong HC, Bourdelas A, Krauss A, Lee HJ, Shao Y, Wu D, Mlodzik M, Shi DL, Zheng J. 2003. Direct binding of the PDZ domain of Dishevelled to a conserved internal sequence in the C-terminal region of Frizzled. Mol Cell 12: $1251-1260$.

Wright KJ, Tjian R. 2009. Wnt signaling targets ETO coactivation domain of TAF4/TFIID in vivo. Proc Natl Acad Sci 106: $55-60$.

Wu J, Klein TJ, Mlodzik M. 2004. Subcellular localization of frizzled receptors, mediated by their cytoplasmic tails, regulates signaling pathway specificity. PLoS Biol 2: E158.

Xing Y, Clements WK, Kimelman D, Xu W. 2003. Crystal structure of a $\beta$-catenin/axin complex suggests a mechanism for the $\beta$-catenin destruction complex. Genes Dev 17: 2753-2764.

Yamamoto H, Komekado H, Kikuchi A. 2006. Caveolin is necessary for Wnt-3a-dependent internalization of LRP6 and accumulation of $\beta$-catenin. Dev Cell 11: 213-223.

Yamashita YM, Jones DL, Fuller MT. 2003. Orientation of Asymmetric Stem Cell Division by the APC Tumor Suppressor and Centrosome. Science 301: 1547-1550.

Yang PT, Lorenowicz MJ, Silhankova M, Coudreuse DY, Betist MC, Korswagen HC. 2008. Wnt signaling requires retromer-dependent recycling of $\mathrm{MIG}-14 /$ Wntless in Wnt-producing cells. Dev Cell 14: 140-147.

Yoo NJ, Kim S, Lee SH. 2008. Mutational analysis of WTX gene in $\mathrm{Wnt} / \beta$-catenin pathway in gastric, colorectal, and hepatocellular carcinomas. Dig Dis Sci doi: 10.1007/s10620-008-0458-9.

Yu X, Waltzer L, Bienz M. 1999. A new Drosophila APC homologue associated with adhesive zones of epithelial cells. Nat Cell Biol 1: 144-151.

Yu HM, Jerchow B, Sheu TJ, Liu B, Costantini F, Puzas JE, Birchmeier W, Hsu W. 2005. The role of Axin2 in calvarial morphogenesis and craniosynostosis. Development 132: 1995-2005.

Zavortink M, Contreras N, Addy T, Bejsovec A, Saint R. 2005. Tum/RacGAP50C provides a critical link between anaphase microtubules and the assembly of the contractile ring in Drosophila melanogaster. J Cell Sci 118: 5381-5392.

Zecca M, Basler K, Struhl G. 1996. Direct and long-range action of a wingless morphogen gradient. Cell 87: 833-844.

Zeng L, Fagatto F, Zhang T, Hsu W, Vasicek TJ, Perry WL, Lee JJ, Tilghman SM, Gumbiner BM, Constantini F. 1997. The mouse Fused locus encodes axin, an inhibitor of 
Wnt Signaling from Development to Disease

the Wnt signaling pathway that regulates embryonic axis formation. Cell 90: 181-192.

Zeng W, Wharton KAJr, Mack JA, Wang K, Gadbaw M, Suyama K, Klein PS, Scott MP. 2000. naked cuticle encodes an inducible antagonist of Wnt signalling. Nature 403: 789-795.

Zeng X, Tamai K, Doble B, Li S, Huang H, Habas R, Okamura H, Woodgett J, He X. 2005. A dual-kinase mechanism for Wnt co-receptor phosphorylation and activation. Nature 438: 873-877.

Zeng X, Huang H, Tamai K, Zhang X, Harada Y, Yokota C, Almeida K, Wang J, Doble B, Woodgett J, et al. 2008.
Initiation of Wnt signaling: Control of Wnt coreceptor Lrp6 phosphorylation/activation via frizzled, dishevelled and axin functions. Development 135: 367-375.

Zhai L, Chaturvedi D, Cumberledge S. 2004. Drosophila wnt-1 undergoes a hydrophobic modification and is targeted to lipid rafts, a process that requires porcupine. J Biol Chem 279: 33220-33227.

Zhang S, Cagatay T, Amanai M, Zhang M, Kline J, Castrillon DH, Ashfaq R, Oz OK, Wharton KAJr. 2007. Viable mice with compound mutations in the Wnt/Dvl pathway antagonists nkd1 and nkd2. Mol Cell Biol 27: 4454-4464. 


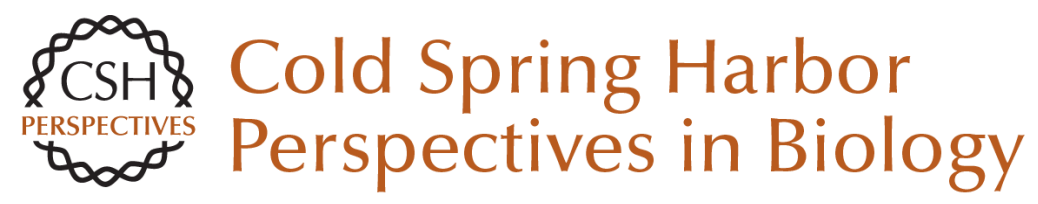

\section{Wnt Signaling from Development to Disease: Insights from Model Systems}

Ken M. Cadigan and Mark Peifer

Cold Spring Harb Perspect Biol 2009; doi: 10.1101/cshperspect.a002881

\section{Subject Collection Cell-Cell Junctions}

Vascular Endothelial (VE)-Cadherin, Endothelial

Adherens Junctions, and Vascular Disease Maria Grazia Lampugnani, Elisabetta Dejana and Costanza Giampietro

Adherens Junctions and Desmosomes

Coordinate Mechanics and Signaling to

Orchestrate Tissue Morphogenesis and Function:

An Evolutionary Perspective

Matthias Rübsam, Joshua A. Broussard, Sara A.

Wickström, et al.

Cell-Cell Contact and Receptor Tyrosine Kinase

Signaling

Christine Chiasson-MacKenzie and Andrea I. McClatchey

Hold Me, but Not Too Tight--Endothelial Cell-Cell Junctions in Angiogenesis

Anna Szymborska and Holger Gerhardt

Connexins and Disease

Mario Delmar, Dale W. Laird, Christian C. Naus, et al.

Cell Junctions in Hippo Signaling

Ruchan Karaman and Georg Halder

Loss of E-Cadherin-Dependent Cell-Cell Adhesion and the Development and Progression of Cancer Heather C. Bruner and Patrick W.B. Derksen
Signaling by Small GTPases at Cell-Cell Junctions: Protein Interactions Building Control and Networks Vania Braga

Making Connections: Guidance Cues and Receptors at Nonneural Cell-Cell Junctions Ian V. Beamish, Lindsay Hinck and Timothy E. Kennedy

The Cadherin Superfamily in Neural Circuit Assembly James $D$. Jontes

Mechanosensing and Mechanotransduction at Cell-Cell Junctions Alpha S. Yap, Kinga Duszyc and Virgile Viasnoff

Beyond Cell-Cell Adhesion: Sensational

Cadherins for Hearing and Balance Avinash Jaiganesh, Yoshie Narui, Raul Araya-Secchi, et al.

Cell-Cell Junctions Organize Structural and Signaling Networks Miguel A. Garcia, W. James Nelson and Natalie Chavez

Cell Biology of Tight Junction Barrier Regulation and Mucosal Disease Aaron Buckley and Jerrold R. Turner

For additional articles in this collection, see http://cshperspectives.cshlp.org/cgi/collection/

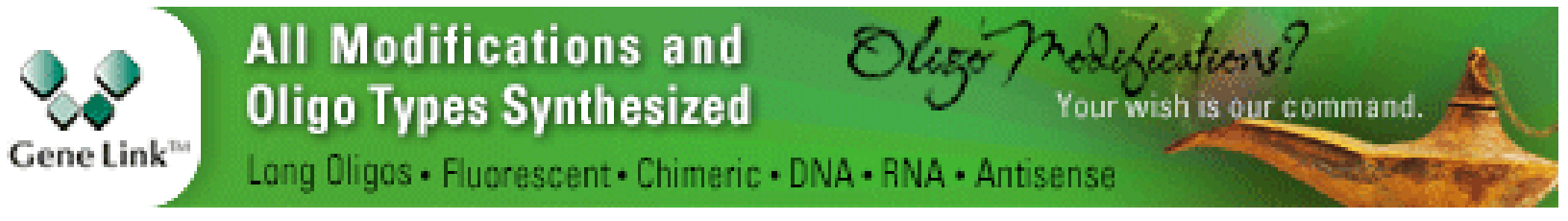


Desmosomes and Intermediate Filaments: Their Consequences for Tissue Mechanics Mechthild Hatzfeld, René Keil and Thomas M. Magin
Integration of Cadherin Adhesion and

Cytoskeleton at Adherens Junctions

René Marc Mège and Noboru Ishiyama

For additional articles in this collection, see http://cshperspectives.cshlp.org/cgi/collection/

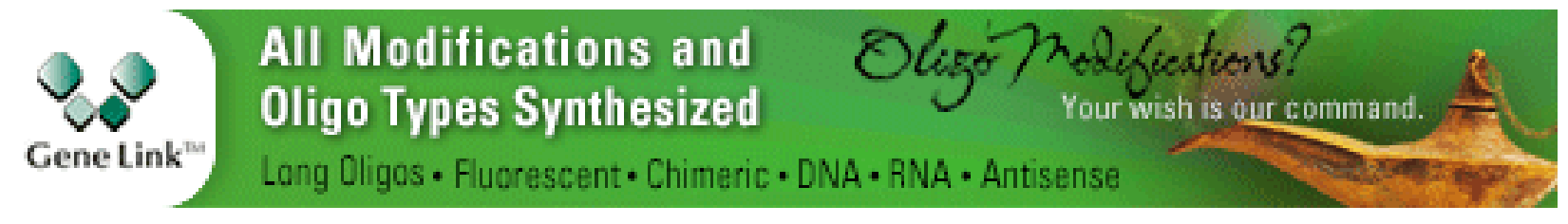

Copyright @ 2009 Cold Spring Harbor Laboratory Press; all rights reserved 